Clim. Past Discuss., doi:10.5194/cp-2016-106, 2016

Manuscript under review for journal Clim. Past

Published: 25 October 2016

(c) Author(s) 2016. CC-BY 3.0 License.

\title{
Two Interglacials: Scientific Objectives and Experimental Designs for CMIP6 and PMIP4 Holocene and Last Interglacial Simulations
}

Bette L. Otto-Bliesner ${ }^{1}$, Pascale Braconnot ${ }^{2}$, Sandy P. Harrison ${ }^{3}$, Daniel J. Lunt ${ }^{4}$, Ayako AbeOuchi $^{5,6}$, Samuel Albani ${ }^{7}$, Patrick J. Bartlein ${ }^{8}$, Emilie Capron ${ }^{9,10}$, Anders E. Carlson ${ }^{11}$, Andrea Dutton $^{12}$, Hubertus Fischer ${ }^{13}$, Heiko Goelzer ${ }^{14,15}$, Aline Govin ${ }^{2}$, Alan Haywood ${ }^{16}$, Fortunat Joos $^{13}$, Allegra N. Legrande ${ }^{17}$, William H. Lipscomb ${ }^{18}$, Gerrit Lohmann ${ }^{19}$, Natalie Mahowald ${ }^{20}$, Christoph Nehrbass-Ahles ${ }^{13}$, Jean-Yves Peterschmitt ${ }^{2}$, Francesco S-R Pausata ${ }^{21}$, Steven Phipps ${ }^{22}$, Hans Renssen ${ }^{23,24}$

$10{ }^{1}$ National Center for Atmospheric Research, 1850 Table Mesa Drive, Boulder, Colorado 80305, United States of America

${ }^{2}$ Laboratoire des Sciences du Climat et de l'Environnement, LSCE/IPSL, CEA-CNRS-UVSQ, Université ParisSaclay, F-91191 Gif-sur-Yvette, France

${ }^{3}$ Centre for Past Climate Change and School of Archaeology, Geography and Environmental Science (SAGES),

University of Reading, Whiteknights, RG6 6AH, Reading, United Kingdom

${ }^{4}$ School of Geographical Sciences, University of Bristol, Bristol, BS8 1SS, UK.

${ }^{5}$ Atmosphere Ocean Research Institute, University of Tokyo, 5-1-5, Kashiwanoha, Kashiwa-shi, Chiba $277-$

20 8564, Japan

${ }^{6}$ Japan Agency for Marine-Earth Science and Technology, 3173-25 Showamachi, Kanazawa, Yokohama,

20 Kanagawa, 236-0001, Japan

${ }^{7}$ Institute for Geophysics and Meteorology, University of Cologne, Cologne, Germany

${ }^{8}$ Department of Geography, University of Oregon, Eugene, OR 97403-1251, United States of America

${ }^{9}$ Centre for Ice and Climate, Niels Bohr Institute, University of Copenhagen, Juliane Maries Vej 30, 2100

Copenhagen Ø, Denmark.

$25{ }^{10}$ British Antarctic Survey, High Cross Madingley Road, Cambridge CB3 0ET, UK

${ }^{11}$ College of Earth, Ocean and Atmospheric Sciences, Oregon State University, Corvallis, OR 97331, United States of America

${ }^{12}$ Department of Geological Sciences, University of Florida, Gainesville, FL 32611

${ }^{13}$ Climate and Environmental Physics, Physics Institute and Oeschger Centre for Climate Change Research,

30 University of Bern, CH-3012 Bern, Switzerland

${ }^{14}$ Institute for Marine and Atmospheric research Utrecht (IMAU), Utrecht University, Princetonplein 5, 3584 CC

Utrecht, The Netherlands

${ }^{15}$ Laboratoire de Glaciologie, Université Libre de Bruxelles, CP160/03, Av. F. Roosevelt 50, 1050 Brussels, Belgium

$35{ }^{16}$ School of Earth and Environment, University of Leeds, Woodhouse Lane, Leeds, West Yorkshire, LS29JT, UK

${ }^{17}$ NASA Goddard Institute for Space Studies, 2880 Broadway, New York, NY 10025, United States of America

${ }^{18}$ Group T-3, Fluid Dynamics and Solid Mechanics, Los Alamos National Laboratory, Los Alamos, NM 87545, United States of America

${ }^{19}$ Alfred Wegener Institute Helmholtz Centre for Polar and Marine Research Bussestr. 24 D-27570 Bremerhaven

40 Germany

${ }^{20}$ Earth and Atmospheric Sciences, Cornell University, Ithaca, NY 14850, United States of America

${ }^{21}$ Department of Meteorology, Stockholm University, 10691 Stockholm, Sweden

${ }^{22}$ Institute for Marine and Antarctic Studies, Uinversity of Tasmania, Hobart, Tasmania 7001, Australia

${ }^{23}$ Department of Earth Sciences, Vrije Universiteit Amsterdam, De Boelelaan 1085, 1081HV Amsterdam, The

Netherlands

${ }^{24}$ Department of Environmental and Health Studies, University College of Southeast Norway, 3800 Bø i Telemark, Norway

Correspondence to: Bette L. Otto-Bliesner (ottobli@ucar.edu) 
Clim. Past Discuss., doi:10.5194/cp-2016-106, 2016

Manuscript under review for journal Clim. Past

Published: 25 October 2016

(c) Author(s) 2016. CC-BY 3.0 License.

Abstract. Two interglacial epochs are included in the suite of paleoclimate simulations in the present phase of the

Coupled Model Intercomparison Project (CMIP6). Equilibrium simulations of the mid-Holocene (midHolocene, 6000 years before present) and the Last Interglacial (lig127k, 127,000 years before present) are designed to examine the impact of changes in orbital forcing at times when atmospheric greenhouse gas levels were similar to those of the preindustrial period and the continental configurations were almost identical to modern. These simulations test our understanding of the interplay between radiative forcing and atmospheric circulation, and the connections among large-scale and regional climate changes giving rise to phenomena such as land-sea contrast and high-latitude amplification in temperature changes, and responses of the monsoons, as compared to today. They also provide an opportunity, through carefully designed additional sensitivity experiments as part of the Paleoclimate Modeling Intercomparison Project (PMIP4), to quantify the strength of atmosphere, ocean, cryosphere, and land-surface feedbacks. Sensitivity experiments are proposed to investigate the role of freshwater forcing in triggering abrupt climate changes within interglacial epochs. These feedback experiments naturally lead to a focus on climate evolution during interglacial periods, which will be examined through transient experiments. Analyses of the sensitivity simulations will also focus on interactions between extratropical and tropical circulation, and the relationship between changes in mean climate state and climate variability on annual to multi-decadal timescales. The comparative abundance of paleoenvironmental data and of quantitative climate reconstructions for the Holocene and Last Interglacial make these two epochs ideal candidates for systematic evaluation of model performance, and such comparisons will shed new light on the importance of external feedbacks (e.g., vegetation, dust) and the ability of state-of-the-art models to simulate climate changes realistically.

Keywords: paleoclimate simulations, transient climate evolution, climate-system feedbacks, interglacial, model evaluation

\section{Introduction}

The modeling of paleoclimate, using physically based tools, has long been used to understand and explain past environmental and climate changes (Kutzbach and Street-Perrott, 1985), and is increasingly seen as a strong out-ofsample test of the models that are used for the projection of future climate changes (Braconnot et al., 2012; Harrison et al., 2014; Harrison et al., 2015; Schmidt et al., 2014). The Paleoclimate Modelling Intercomparison Project (PMIP) has served to coordinate paleoclimate experiments and data-model comparisons for several decades (Braconnot et al., 2012; Braconnot et al., 2007a; Braconnot et al., 2007b; Joussaume and Taylor, 1995; Joussaume et al., 1999), and now spearheads the paleoclimate contribution to the current phase of the Coupled Model Intercomparison Project (CMIP6, Eyring et al., 2016). Several paleoclimate experiments are included in CMIP6 (Kageyama et al., 2016): two of these experiments focus on comparing the most recent interglacial epochs and specifically the current interglacial (the Holocene) and the previous interglacial (the Last Interglacial, LIG) periods (Fig. 1). These two experiments are of interest because they examine the response of the climate system to relatively simple changes in forcing compared to the present. The main difference in forcing from present was in the latitudinal and seasonal distribution of incoming solar radiation (insolation) caused by known changes in the Earth's 
Clim. Past Discuss., doi:10.5194/cp-2016-106, 2016

Manuscript under review for journal Clim. Past

Published: 25 October 2016

(c) Author(s) 2016. CC-BY 3.0 License.

orbit; greenhouse gas (GHG) concentrations were similar to those of the preindustrial period and the continental

configurations were also very similar to modern. The changes in insolation are characterized by enhanced seasonal contrast in the northern hemisphere $(\mathrm{NH})$ (and reduced seasonal contrast in the southern hemisphere, $\mathrm{SH}$ ), giving rise to warmer $\mathrm{NH}$ summers and a significant enhancement of the $\mathrm{NH}$ monsoons. Differences in orbital configuration between the two interglacial periods (Berger, 1978) mean that these changes are stronger in the LIG than in the Holocene, but the observational basis for evaluating model simulations is more extensive in the Holocene than the LIG because of preservation issues (Harrison et al., 2016). Taken together, these two interglacial periods are good test cases of our mechanistic understanding of the interplay between radiative forcing and atmospheric circulation, and opportunities to examine connections among large-scale and regional climate changes which give rise to phenomena such as land-sea contrast and high-latitude amplification of temperature changes, the regulation of atmospheric $\mathrm{CO}_{2}$ and biogeochemical cycles, and the waxing and waning of the monsoons.

The core interglacial experiments for CMIP6 are time-slice (or equilibrium) experiments at 6000 and 127,000 years before present (where present is defined as 1950), hereafter referred to as $6 \mathrm{ka}$ (midHolocene) and $127 \mathrm{ka}$ (lig127k). The mid-Holocene interval has been the focus for model simulations, model-model comparisons, paleodata synthesis, and model-data comparison since the beginning of PMIP, and this work has contributed to model evaluation and understanding of climate change in the last three major assessments of the Intergovernmental Panel on Climate Change (Flato et al., 2013; Folland et al., 2001; Hegerl et al., 2007; Jansen et al., 2007; MassonDelmotte et al., 2013). Systematic benchmarking against pollen-based reconstructions of climate variables and lakelevel-based water-balance reconstructions (Braconnot et al., 2012; Braconnot et al., 2007b; Coe and Harrison, 2002; Harrison et al., 2014; Harrison et al., 2015; Harrison et al., 1998) have highlighted that climate models persistently underestimate changes in the monsoon precipitation and produce too much continental drying (Harrison et al., 2015). This raises questions about the role of systematic model biases on simulated climate changes and on the level of model complexity required to simulate climate changes correctly.

Given the long history of coordinated model experiments for $6 \mathrm{ka}$, this period allows us to assess whether there is an improvement in the ability of models to reproduce a climate state different from the modern one. For this reason the Tier 1 midHolocene experiment is one of two possible entry cards for PMIP simulations in CMIP6 (Table 1): all modeling groups contributing to PMIP4-CMIP6 must perform either the midHolocene experiment or a simulation of the Last Glacial Maximum (Kageyama et al., 2016).

Although the LIG (129 ka to $116 \mathrm{ka}$ ) was discussed in the First Assessment Report of the IPCC (Folland et al., 1990), it gained more prominence in the IPCC Fourth and Fifth Assessment (AR4 andAR5) because of reconstructions highlighting that global mean sea level was at least $5 \mathrm{~m}$ higher (but probably no more than $10 \mathrm{~m}$ higher) than present for several thousand years (Dutton et al., 2015a; Jansen et al., 2007; Masson-Delmotte et al., 2013). Thus the LIG is recognized as an important period for testing our knowledge of climate-ice sheet interactions in warm climate states. However, the ensemble of LIG simulations examined in the AR5 (Masson-Delmotte et al., 2013) was not wholly consistent: the orbital forcing and GHG concentrations varied between the simulations. While it has been suggested that differences in regional temperatures between models might reflect differences in 
Clim. Past Discuss., doi:10.5194/cp-2016-106, 2016

Manuscript under review for journal Clim. Past

Published: 25 October 2016

(c) Author(s) 2016. CC-BY 3.0 License.

120 cryosphere feedback strength (Yin and Berger, 2012; Otto-Bliesner et al., 2013) or differences in the simulation of the Atlantic Meridional Overturning Circulation (AMOC) (Bakker et al., 2013; Masson-Delmotte et al., 2013), differences between models could also have arisen because of differences in the experimental protocols. Furthermore, the LIG simulations were mostly made with older and/or lower-resolution versions of the models than were used for future projections, making it more difficult to use the results to assess model reliability (Lunt et al., 2013). The Tier 1 lig127k experiment (Table 1) is designed to address the climate responses to stronger orbital forcing than the midHolocene experiment using the same state-of-the-art models and following a common experimental protocol. It will provide a basis to address the linkages between ice sheets and climate change in collaboration with the Ice Sheet Model Intercomparison Project for CMIP6 (ISMIP6) (Nowicki et al., 2016).

The midHolocene and lig127k experiments are starting points for examining interglacial climates. A number of other experiments will be made in the current phase of PMIP (PMIP4) to facilitate diagnosis of these "Tier 1" experiments (Tier 1 experiments are those associated with CMIP6, Tier 2 simulations are sensitivity studies in the framework of PMIP4, but not CMIP6). These will include sensitivity experiments to examine the impact of uncertainties in boundary conditions and the role of feedbacks in modulating the response to orbital forcing. Ocean, vegetation, and dust feedbacks, and the synergies between them, have been a focus in previous phases of PMIP (Braconnot et al., 1999; Dallmeyer et al., 2010; Otto et al., 2009; Wohlfahrt et al., 2004) and this allows us to design simple experimental protocols to compare the strength of these feedbacks in different climate models. Simulations with prescribed but realistic vegetation cover will be a major focus for both the Holocene and LIG in PMIP4, and comparison of these simulations with ESM simulations that include dynamic vegetation will allow exploration of the magnitude of land-surface biases in these latter models. Changes in vegetation and land-surface hydrology are an important control on dust emissions (Tegen et al., 2002; Engelstädter et al., 2003), which can affect the strength of the West African Monsoon (Konare et al. 2008, Pausata et al. 2016). The examination of the dust feedback will be a new focus in PMIP4. In addition, the LIG provides an ideal opportunity to examine the role of cryosphere feedbacks through sensitivity experiments, which will be a focus of additional experiments associated with both the Holocene and the LIG. One such feedback is the release of freshwater into the ocean and the role of such freshwater forcing in generating more abrupt climate changes than would be expected for the smoothly varying changes in insolation forcing during an interglacial (Goelzer et al., 2016a; Luan et al., 2015; Stone et al., 2016). Understanding the role of feedbacks in general on the generation of abrupt climate changes, and the need to understand the relationship between mean climate changes and short-term (annual to multi-decadal) climate variability, leads naturally to a desire to simulate the transient behavior of the climate system - and such transient experiments will be made for 150 both the Holocene and LIG time periods. New results have highlighted the possibility to use reconstruction of past interannual variability from corals and mullusc shells to assess the Holocene simulated changes in variability at the scale of the tropical Pacific Ocean (Emile-Geay et al. 2016). Groups are also encouraged to run their models with an active land and ocean carbon cycle to assess terrestrial and ocean carbon storage and differences between the two interglacial periods. 
Clim. Past Discuss., doi:10.5194/cp-2016-106, 2016

Manuscript under review for journal Clim. Past

Published: 25 October 2016

(c) Author(s) 2016. CC-BY 3.0 License.

The aim of this paper is to present and explain the experimental design both for the PMIP4-CMIP6 Tier 1 interglacial experiments, and for associated Tier 2 sensitivity and transient experiments. Section 2 describes and discusses the PMIP4-CMIP6 midHolocene entry card and lig127k Tier 1 simulations. Section 3 describes Tier 2 PMIP4 sensitivity studies that can be carried out to diagnose these core simulations. Section 4 briefly describes the paleodata resources, which can be used to evaluate the simulations.

\section{Experimental design for the PMIP4-CMIP6 midHolocene and lig127k simulations}

The core or Tier 1 experiments for the Holocene and the LIG are the midHolocene and lig127k simulations. The CMIP DECK piControl for 1850 C.E and the CMIP6 historical experiment (see Eyring et al. 2016 for description of these experiments) are the reference simulations to which the paleo-experiments will be compared. Thus, the paleo-experiments must use the same model components and follow the same protocols for implementing external forcings as are used in the piControl and historical simulations. The midHolocene simulation is one of the PMIP entry cards in the PMIP4-CMIP6 experiments, which means that groups who run the lig127k simulation must also run either the midHolocene or the lgm (Last Glacial Maximum) experiment (Kageyama et al., 2016). The boundary conditions for the midHolocene, lig127k, and piControl experiments are given in Table 1, and more detailed information is given below.

\subsection{Orbital configuration, solar constant, and insolation anomalies}

Earth's orbital parameters (eccentricity, longitude of perihelion, and obliquity) should be prescribed following Berger and Loutre (1991). These parameters affect the seasonal and latitudinal distribution and magnitude of solar energy received at the top of the atmosphere and, in the case of obliquity, the annual mean insolation at any given latitude (Berger and Loutre, 1991). The DECK piControl simulations are to use the orbital parameters appropriate for 1850 C.E (Table 1) (Eyring et al., 2016), when perihelion occurs close to the boreal winter solstice. The exact date slightly varies depending on the internal model calendar and the number of days used to define a year. Because of this and the fact that the length of the seasons varies as a function of precession and eccentricity (Joussaume and Braconnot, 1997), the vernal equinox must be set to noon on March 21th in all the simulations (piControl, midHolocene and lig127k). The orbit at $127 \mathrm{ka}$ was characterized by larger eccentricity than at 1850 C.E., with perihelion occurring close to the boreal summer solstice (Fig. 2). The tilt of the Earth's axis was maximal at $131 \mathrm{ka}$ and remained higher than in 1850 C.E. through $125 \mathrm{ka}$; obliquity at $127 \mathrm{ka}$ was $24.04^{\circ}$ (Table 1). The orbit at $6 \mathrm{ka}$ was characterized by an eccentricity of 0.018682 , similar to 1850 C.E. Obliquity was similar though slightly larger $\left(24.105^{\circ}\right)$ than at $127 \mathrm{ka}$, and perihelion at $6 \mathrm{ka}$ occurred near the boreal autumn equinox. The different orbital configurations for the midHolocene and lig127k result in different seasonal and latitudinal distribution of top-ofatmosphere insolation compared to the DECK piControl (Fig. 3). Both time periods show large positive insolation anomalies during boreal summer. July-August anomalies between 40 and $50^{\circ} \mathrm{N}$ reach about $55-60 \mathrm{~W} \mathrm{~m}^{-2}$ at $127 \mathrm{ka}$ and $25 \mathrm{~W} \mathrm{~m}^{-2}$ at $6 \mathrm{ka}$. The higher obliquity at $127 \mathrm{ka}$ and $6 \mathrm{ka}$ contributes to a small but positive annual insolation anomaly compared to preindustrial at high latitudes in both hemispheres. The global difference in insolation forcing between the interglacial experiments and the preindustrial is negligible. 
Clim. Past Discuss., doi:10.5194/cp-2016-106, 2016

Manuscript under review for journal Clim. Past

Published: 25 October 2016

(c) Author(s) 2016. CC-BY 3.0 License.

The difference in orbital configuration between $127 \mathrm{ka}, 6 \mathrm{ka}$ and preindustrial means that there are differences in season length that should be accounted for in calculating seasonal changes (Kutzbach and Gallimore, 1988). The bias introduced from using the modern calendar rather than the celestial calendar to calculate seasonal averages is shown in Fig. 2, when the date of the vernal equinox is assigned to March 21 at noon. To be able to account for this effect when comparing the simulations to the paleoclimate reconstructions, daily outputs of at least surface temperature, precipitation and winds must be archived. Programs that provide an approximate estimate of monthly means on the fixed-angular celestial calendar from fixed-day calendar will be available on the PMIP4 web page.

The solar constant prescribed for the midHolocene and lig127k simulations is the same as in the DECK piControl simulation, which is fixed at the mean value for the first two solar cycles of the historical simulation (i.e. 18501871) (Eyring et al., 2016). This value $\left(1360.7 \mathrm{~W} \mathrm{~m}^{-2}\right)$ is lower than the value for the solar constant used by some models in PMIP3 $\left(1365 \mathrm{~W} \mathrm{~m}^{-2}\right)$ and this leads to a global reduction of incoming solar radiation compared to the PMIP3 experiments (Fig. 4). The slight differences in orbital parameters between the 1850 CE reference periods to be used for PMIP4-CMIP6 and the 1950 CE reference used for PMIP3 leads to seasonal differences in forcing with a slight decrease in boreal spring and increase in boreal autumn. The combination of the two factors leads to an overall reduction: the largest reduction occurs in boreal spring and is about $1.6 \mathrm{~W} \mathrm{~m}^{-2}$ between $10^{\circ} \mathrm{S}$ and $40^{\circ} \mathrm{N}$.

\subsection{Greenhouse gases}

Ice-core records from Antarctica and Greenland provide measurements of the well-mixed GHGs: $\mathrm{CO}_{2}, \mathrm{CH}_{4}$, and $\mathrm{N}_{2} \mathrm{O}$ (Fig. 1). These measurements are given as molar mixing ratios in dry air in units of parts per million (ppm) or parts per billion (ppb) respectively. For simplicity, we use the term 'concentration' for these mixing ratios. By 6 ka and $127 \mathrm{ka}$, the concentrations of atmospheric $\mathrm{CO}_{2}$ and $\mathrm{CH}_{4}$ had increased from their respective levels during the previous glacial periods, the Last Glacial Maximum and the penultimate glaciation, to values comparable to preindustrial levels.

215 midHolocene. In PMIP4-CMIP6, we use a revised version of an earlier trace gas reconstruction (Joos and Spahni, 2008). The $\mathrm{CO}_{2}$ concentration for the mid-Holocene is derived from ice-core measurements from Dome Concordia (Monnin et al., 2001; Monnin et al., 2004) and dated using the AICC2012 age scale (Veres et al., 2013). A smoothing spline (Bruno and Joos, 1997; Enting, 1987) with a nominal cut-off period of 3000 years was used to produce a continuous $\mathrm{CO}_{2}$ record. This yields a $\mathrm{CO}_{2}$ concentration of $264.4 \mathrm{ppm}$ at $6 \mathrm{ka}$. Methane was measured in ice from Antarctic ice cores EDC (Fluckiger et al., 2002), Dronning Maud Land (EPICA Community Members, 2006) and Talos Dome (TALDICE). For Greenland, methane data are from GRIP (Blunier et al., 1995; Chappellaz et al., 1997; Spahni et al., 2003), GISP2 (Brook, 2009), and GISP2D (Mitchell et al., 2013). Both are splined with a nominal cut-off period of 200 years. This results in a concentration of $574 \mathrm{ppb}$ for the Antarctic ice cores, representative for high latitude Southern Hemisphere air, and of $620 \mathrm{ppb}$ for the Greenland ice cores, representative for the high latitude Northern Hemisphere air, and an estimated global mean value of $597 \mathrm{ppb}$. The $\mathrm{N}_{2} \mathrm{O}$ data around $6 \mathrm{ka}$ are from a compilation of published data from EDC (Fluckiger et al., 2002; Spahni et al., 2005) and new, 
Clim. Past Discuss., doi:10.5194/cp-2016-106, 2016

Manuscript under review for journal Clim. Past

Published: 25 October 2016

(c) Author(s) 2016. CC-BY 3.0 License.

unpublished data measured at University of Bern using ice from Greenland (NGRIP) and Talos Dome (TALDICE). The data are splined with a nominal cut-off period of $700 \mathrm{yr}$ and the resulting $\mathrm{N}_{2} \mathrm{O}$ concentration at 6 ka is $262 \mathrm{ppb}$.

The realistic GHG concentrations used for the midHolocene PMIP4-CMIP6 experiment are different from those used in the PMIP3 experiments (Braconnot et al. 2012). The PMIP3 experiments were designed simply to examine the effects of changes in orbital forcing, and the $\mathrm{CO}_{2}$ concentrations were therefore kept the same as the value typically used in pre-industrial experiments $(280 \mathrm{ppm})$ although other GHGs were prescribed from ice-core measurements. The use of realistic values for all the GHGs in the PMIP4-CMIP6 midHolocene experiment may improve comparisons with paleoclimate reconstructions and will ensure that the midHolocene experiment is consistent with planned transient Holocene simulations (see Section 3). However, the reduction in $\mathrm{CO}_{2}$ concentration from 280 to $264.4 \mathrm{ppm}$ will reduce GHG forcing by about $0.3 \mathrm{~W} \mathrm{~m}^{2}$ (Myhre et al., 1998), which translates to a difference in global mean surface air temperature of $-0.24^{\circ} \mathrm{C}$ when applying an equilibrium climate sensitivity of $3^{\circ} \mathrm{C}$ for a nominal doubling of $\mathrm{CO}_{2}$. Simulations with the IPSL model (Dufresne and co-authors, 2013) show that this change in the experimental protocol between PMIP3 and PMIP4-CMIP6 yields a global mean cooling of $0.24 \pm 0.04^{\circ} \mathrm{C}$, as expected, but that there are regional differences of up to $0.5^{\circ} \mathrm{C}$ in parts of Eurasia and in South Africa (Fig. 5). Although these differences are small overall, they will need to be accounted for in comparisons between the PMIP4-CMIP6 midHolocene simulations and previous generations of PMIP 6ka simulations.

lig127k. The LIG GHG concentrations are available solely from Antarctic ice cores. $\mathrm{CO}_{2}$ concentrations can only be derived from Antarctic ice, because of potential in-situ $\mathrm{CO}_{2}$ production in the Greenland ice sheet (Tschumi and Stauffer, 2000). We also do not have any reliable $\mathrm{CH}_{4}$ and $\mathrm{N}_{2} \mathrm{O}$ concentrations from Greenland in the LIG due to melt layers in the ice, as Greenland temperatures were significantly warmer at that time compared to modern (Fig. 1) (NEEM Community Members 2013). For the lig127k simulation (Table 1), we adopt mean values for 127.5-126.5 ka on the AICC2012 age scale (Bazin et al., 2013) from EPICA Dome C (Bereiter et al., 2015; Schneider et al., 2013) for $\mathrm{CO}_{2}$, from EPICA Dome C and EPICA Dronning Maud Land (Loulergue et al., 2008; Schilt et al., 2010) for $\mathrm{CH}_{4}$, as well as from EPICA Dome $\mathrm{C}$ and Talos Dome (Schilt et al., 2010) for $\mathrm{N}_{2} \mathrm{O}$. The atmospheric $\mathrm{CO}_{2}$ and $\mathrm{N}_{2} \mathrm{O}$ concentrations of $275 \mathrm{ppm}$ and $255 \mathrm{ppb}$, respectively, can be regarded as globally representative, while the mean ice core $\mathrm{CH}_{4}$ concentration (662 ppb) is representative for high-latitude Southern Hemisphere air. A global mean atmospheric $\mathrm{CH}_{4}$ concentration of $685 \mathrm{ppb}$ is adopted for $127 \mathrm{ka}$, thereby assuming the same difference (23 ppb) between the global mean atmospheric $\mathrm{CH}_{4}$ and Antarctic ice core $\mathrm{CH}_{4}$ values as for the mid-Holocene.

\subsection{Paleogeography and ice sheets}

midHolocene. Several lines of evidence indicate that the ice sheets had their modern characteristics by the midHolocene, except in a few places such as the Baffin Islands (Carlson et al., 2008b; Clark et al., 2000). While the presence of a relict of the Laurentide ice sheet may be the origin of model-data mismatches in the climate of eastern North America (Wohlfahrt et al., 2004), the effect is local and small. Cosmogenic surface exposure ages and threshold lake records (Carlson et al., 2014; Larsen et al., 2015; Sinclair et al., 2016) also suggest that by 6 ka, the Greenland ice sheet was similar in extent to the present. Uncertainties in the reconstructions of this relict ice sheet 
Clim. Past Discuss., doi:10.5194/cp-2016-106, 2016

Manuscript under review for journal Clim. Past

Published: 25 October 2016

(c) Author(s) 2016. CC-BY 3.0 License.

would have a larger impact on the simulations, and thus ice sheet distribution and elevations, land-sea mask, continental topography and oceanic bathymetry should all be prescribed as the same as in piControl in the midHolocene simulation (Table 1).

lig127k. Evidence for the evolution of the ice sheets during the LIG comes mainly from proximal marine records (Carlson and Winsor, 2012). The deposition of a detrital carbonate layer in the Labrador Sea, dated to around 128 ka based on geomagnetic secular variation (Winsor et al., 2012), suggests that ice had retreated from Hudson Bay and is taken to indicate the final demise of the Laurentide ice sheet (Carlson, 2008; Nicholl et al., 2012). The disappearance of the Eurasian ice sheet is more difficult to constrain because either the proximal marine records lack benthic $\delta^{18} \mathrm{O}$ data, or the benthic $\delta^{18} \mathrm{O}$ data show trends that are different from those of open ocean records during the LIG (Bauch, 2013). The cessation of deposition of ice-rafted debris (IRD) from the Eurasian ice sheet was dated to between 128-126 ka using $\delta^{18} \mathrm{O}$ (Risebrobakken et al., 2006). However, sea-level (Dutton et al., 2015b) and icecore (Lecavalier and Markle, 2016) data suggest that this ice sheet disappeared earlier and was likely gone by $\sim 127$ ka. Proximal marine records of the Greenland ice sheet document a gradual retreat during the LIG, with minimum extent around 120 ka (Carlson et al., 2008a; Colville et al., 2011; Stoner et al., 1995; Winsor et al., 2012). However, Greenland-sourced IRD reached a minimum similar to the Holocene before $\sim 127$ ka (Colville et al., 2011; Winsor et al., 2012).

The extent of the Antarctic ice sheets is not directly constrained by data proximal to the ice sheet at 127 ka. Given higher-than-present sea levels, the gradual retreat of the Greenland ice sheet, and the lack of other NH ice sheets, it seems likely that the Antarctic ice sheet was smaller than present by $\sim 127$ ka (Colville et al., 2011; Dutton et al., 2015a; Dutton et al., 2015b; Mercer, 1978). The existence of $\sim 250 \mathrm{ka}$ Mt. Erebus ash in the ANDRILL site in Ross Sea could indicate a smaller-than-present West Antarctic ice sheet (WAIS) some time after $250 \mathrm{ka}$ (McKay et al., 2012). The ice-core record from Mount Moulton, West Antarctica suggests deglaciation of much of West Antarctica during the LIG, and likely at 126-130 ka (Steig et al., 2015). Standalone ice sheet model simulations forced by ocean warming suggest the West Antarctic ice sheet to be a major contributor to LIG global mean sea level rise, with contributions also coming from the marine-based portions of the East Antarctic ice sheet (DeConto and Pollard, 2016). Contributions are 6.0-7.5 m of equivalent sea-level rise, which would explain global mean sea level being at least $+6 \mathrm{~m}$ by $\sim 127 \mathrm{ka}$ (Dutton et al., 2015b). However, because of the difficulty in implementing ice-to-ocean changes for the WAIS and the uncertainties associated with dating the changes in the other ice sheets, the paleogeography of the lig127k simulation will be prescribed the same as in the DECK piControl simulation (Table 1). In view of the greater uncertainty associated with the prescription of ice sheets in the lig $127 \mathrm{k}$ experiment, this aspect of the boundary conditions will be a major focus of sensitivity experiments (see Section 3 ).

\subsection{Vegetation}

There is abundant evidence for changes in vegetation distribution during the mid-Holocene and the LIG (Goni et al., 2005; Harrison and Bartlein, 2012; Hely et al., 2014; LIGA Members, 1991; Prentice et al., 2000). However, there is insufficient data coverage for many regions to be able to produce reliable global vegetation maps. Furthermore, 
Clim. Past Discuss., doi:10.5194/cp-2016-106, 2016

Manuscript under review for journal Clim. Past

Published: 25 October 2016

(c) Author(s) 2016. CC-BY 3.0 License.

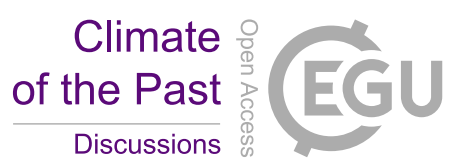

given the very different levels of complexity in the treatment of vegetation properties, phenology and dynamics in the current generation of climate models, paleo-observations do not provide sufficient information to constrain their behavior in a comparable way. The treatment of natural vegetation in the midHolocene and lig127k simulations should therefore be the same as in the DECK piControl simulation. That is, depending on what is done in the DECK piControl simulation, vegetation should either be prescribed to be the same as in that simulation, or prescribed but with interactive phenology, or predicted dynamically (Table 1). Uncertainties related to the treatment of vegetation in the different simulations will be analyzed through sensitivity experiments (see section 3 ).

\subsection{Aerosols: tropospheric dust and stratospheric volcanic}

305 Natural aerosols show large variations on glacial-interglacial time scales, with low aerosol loadings during interglacials compared to glacials, and during the peak of the interglacials compared to present day (Albani et al., 2015; deMenocal et al., 2000; Kohfeld and Harrison, 2000). Atmospheric dust affects radiative forcing at a regional scale and can therefore affect precipitation and surface hydrology (Miller et al., 2004; Yoshioka et al., 2007) including the monsoons (Konare et al., 2008; Pausata et al., 2016; Vinoj et al., 2014) as well as moderating snow

310 albedo feedbacks when sufficient dust is deposited (Krinner et al., 2006). While model simulations that are observationally constrained by a global compilation of dust records suggest that the global dust budget was dominated by $\mathrm{NH}$ dynamics during the midHolocene as it is today, the regional patterns of dust loading were different (Albani et al., 2015). This motivates the inclusion of changes in dust loading in the midHolocene and lig127k simulations (Table 1, Figure 6).

315 As in the case of vegetation, the implementation of changes in atmospheric aerosol in the midHolocene and lig127k simulations should follow the treatment used for the DECK pre-industrial and historical simulations. Models with an interactive representation of dust should prescribe changes in soil erodibility or dust emissions to account for the changes in dust sources during the interglacials (datasets available at https://pmip4.1sce.ipsl.fr/doku.php/exp_design:mh). Although the maps provided by PMIP for this purpose are for mid-Holocene conditions and from the only model simulation available (Albani et al., 2015) it should be used for both the midHolocene and lig127k simulations. For each model configuration, if atmospheric dust loading is prescribed in the DECK piControl and historical simulations, the midHolocene and lig127k simulations should use the three-dimensional monthly climatology of atmospheric dust mass concentrations or aerosol optical depths available from the same data-constrained simulations as the soil erodibility maps. Also available are datasets of the dust shortwave and longwave direct radiative forcing. If atmospheric dust loading is not represented in the DECK piControl and historical simulations, it should not be included in the midHolocene and lig127k simulations. The impact of dust on the radiation balance is sensitive to the optical properties prescribed (Perlwitz et al., 2001); it is uncertain how optical properties might change during interglacials (Potenza et al., 2016; Royer et al., 1983). Uncertainties in the protocol and in the interplay between dust and vegetation will be a focus of the analyses.

330 There is no observationally-constrained estimate of the volcanic stratospheric aerosol for either the mid-Holocene or the LIG. The background volcanic stratospheric aerosol used in the CMIP6 DECK piControl should be used for the 
Clim. Past Discuss., doi:10.5194/cp-2016-106, 2016

Manuscript under review for journal Clim. Past

Published: 25 October 2016

(c) Author(s) 2016. CC-BY 3.0 License.

midHolocene and lig127k simulations. Other aerosols included in the DECK piControl should similarly be included in the midHolocene and lig $127 \mathrm{k}$ simulations.

\subsection{Setup and documentation of simulations}

Spin-up procedures differ for different models, but the model must be run for long enough to avoid long-term drift in the global energetics and major climate variables, including intermediate ocean temperatures. A minimum of 500 years for the total length of simulation is required, assuming an initialization from modern ocean conditions. The outputs stored in the CMIP6 database should be representative of the equilibrium climates of the midHolocene and lig $127 \mathrm{k}$ time periods. A minimum of 100 years of output is required to be uploaded for each simulation (usually the 340 final 100 years of the simulation). However, given the increasing interest in analyzing multi-decadal variability (e.g. Wittenberg, 2009) and the availability of reconstructions of ENSO (E1 Niño-Southern Oscillation) and other modes of variability (see Sect. 3), modeling groups are encouraged to provide outputs for at least 500 years if possible.

The simulations should follow the CMIP6 data request and format. For groups only contributing to PMIP, the data format and organization on the ESGF archive is the same as for CMIP6, except that the provision of daily values can be limited to $2 \mathrm{D}$ surface variables, including temperature, precipitation and winds. Groups are also asked to keep a 20 year period with all the output needed to force regional area-limited models, since we would like to strengthen the linkages between global and regional simulations for regional model-data comparisons.

The required detailed documentation of the PMIP4-CMIP6 simulations is documented in Kageyama et al., 2016. Documentation should be provided via the ESDOC website and tools provided by CMIP6 (http://es-doc.org/) to facilitate communication with other CMIP6 projects. This documentation should be mirrored on the PMIP4 website to facilitate linkages with non-CMIP6 simulations to be carried out in PMIP4. For the midHolocene and lig127k, the documentation should include:

- A description of the model and its components;

355 - Information on the implementation of the forcings. The provision of figures and tables giving monthly-latitude insolation anomalies and daily incoming solar radiation at the top of the atmosphere (TOA) for one year should be provided because this allows the implementation of the most critical forcing to be checked. Information about the implementation of aerosols should also be provided. Any differences from the protocols in Table 1 need to be documented;

360 - Information about the initial conditions and spin-up technique used, as well as any information about model tuning that could affect albedo, climate thresholds or climate variability. A measure of the changes and drifts in key variables (e.g., globally averaged $2 \mathrm{~m}$ temperatures, sea-surface temperatures, bottom ocean temperatures, and topof-the-atmosphere radiative fluxes) should be provided.

\section{PMIP4 Additional Simulations}


Clim. Past Discuss., doi:10.5194/cp-2016-106, 2016

Manuscript under review for journal Clim. Past

Published: 25 October 2016

(c) Author(s) 2016. CC-BY 3.0 License.

365 The selection of only two intervals, midHolocene and lig127k, for PMIP4-CMIP6 interglacial experiments is designed to maximize both the model ensemble size and opportunities for model evaluation, since both periods have been the focus for data synthesis. However, this means that the experiments do not sample the diversity in the transient forcings and responses during the LIG and the Holocene. Although transient simulations for these two periods are included in the suite of PMIP4 simulations (see 3.5), there is utility in examining other interglacial climates using equilibrium experiments parallel to the midHolocene and lig127k simulations, particularly in order to provide additional samples of the response of the system to insolation forcing. Additional, Tier 2 experiments - the end of the LIG (116 ka) and the early Holocene (9.5 ka) (see 3.1) - are proposed to address this.

Uncertainties in the boundary and initial conditions for the mid-Holocene and LIG mean that the PMIP4-CMIP6 midHolocene and lig127k simulations may not capture important feedbacks accurately. The major sources of uncertainty in the boundary conditions are the prescription of modern vegetation cover by some models, and the prescription of modern ice sheets in the lig $127 k$ simulation. Both sources of uncertainty can be addressed through Tier 2 sensitivity experiments (see 3.2,3.3). The equilibrium experiments also do not address climate changes forced by the non-linear behavior of ice sheet-ocean coupling, or the possibility that such feedbacks could give rise to abrupt changes in climate superimposed on the more slowly-varying insolation forcing during the Holocene and the LIG. This will be addressed through Tier 2 idealized simulations of specific freshwater-forcing events, specifically the Heinrich 11 event at the beginning of the LIG and the 8.2 ka event during the Holocene (see 3.4). Other feedbacks could give rise to more abrupt responses to orbital forcing. Understanding the interplay among different components of the Earth system in determining the long-term evolution of LIG and Holocene climate is the major goal of the proposed Tier 2 transient experiments (Section 3.5) to be carried out during PMIP4.

Further information and access to datasets is available on PMIP4 web site and will be updated during the course of the project (https://pmip4.1sce.ipsl.fr/doku.php/exp_design:index)

\subsection{Equilibrium response to alternative states of orbital forcing}

390 Early Holocene. The maximum expression of orbitally-induced differences in TOA insolation forcing from present occurred during the early part of the Holocene, but the climate at this time was still affected by the presence of a relict of the Laurentide ice sheet (Carlson et al., 2008b). As a result, summer temperatures in mid- to high latitudes were cooler than during the mid-Holocene (Carlson et al., 2008b; Renssen et al., 2012; Renssen et al., 2009). The presence of the ice sheet delayed the response to insolation forcing in monsoon regions (Lezine et al., 2011; Marzin et al., 2013). It has also been suggested that the remnant ice-sheet may have counteracted the reduction of ENSO variability in response to orbital forcing in the early Holocene (Carre et al., 2014; Luan et al., 2015). Protocols for early Holocene experiments were developed in previous phases of PMIP (PMIP2, PMIP3), and provide the basis for proposed PMIP4 simulation for $9.5 \mathrm{ka}$. Since the phase of precession at $9.5 \mathrm{ka}$ is similar to that of $127 \mathrm{k}$, this experiment provides a basis for examination of the similarities in seasonal changes between the two interglacials (Braconnot et al., 2008). Following the experimental protocol for the midHolocene simulation, orbital parameters 
Clim. Past Discuss., doi:10.5194/cp-2016-106, 2016

Manuscript under review for journal Clim. Past

Published: 25 October 2016

(c) Author(s) 2016. CC-BY 3.0 License.

should be changed following Berger and Loutre (1991). The extent and topography of the ice sheet should be prescribed using either ICE-6G or GLAC-1D, as proposed by the PMIP deglaciation working group (Ivanovic et al., 2016). GHG concentrations can also be prescribed from the last deglaciation experiment.

Lig116k Continental ice sheet growth and associated sea level lowering started at $\sim 116 \mathrm{ka}$, marking the end of the LIG (Stirling et al., 1998). Simulations with climate models that include feedbacks among the atmosphere, ocean, land, and sea ice are able to simulate sufficient cooling to initiate ice sheet growth when forced with the 116 ka orbital conditions reducing NH summer insolation (Herrington and Poulsen, 2012; Jochum et al., 2012). However, the result is sensitive to the atmospheric $\mathrm{CO}_{2}$ concentration used. In order to test the sensitivity to $\mathrm{CO}_{2}$, we propose sensitivity experiments using orbital parameters for $116 \mathrm{ka}$ (ligl16k). In the first experiment, the $\mathrm{CO}_{2}$ concentration should be prescribed as $280 \mathrm{ppm}$, while in the second experiment it should be set to $240 \mathrm{ppm}$. All other forcings and boundary conditions will remain the same as the lig $127 k$ simulation.

\subsection{Sensitivity to Prescribed Vegetation}

Except in the case of models with dynamic vegetation, the midHolocene and lig $127 k$ simulations will be run with prescribed preindustrial vegetation cover because of the lack of a comprehensive and reliable global data set of vegetation for the two periods. However, pollen and macro-fossil evidence show that boreal forest extended farther north than today in the mid-Holocene (Bigelow and al., 2003; Prentice et al., 2000) and, except in Alaska and central Canada, extended to the Arctic coast during the LIG (Edwards et al., 2003; LIGA, 1991; Lozhkin and Anderson, 1995). Pollen and other biogeographical/geomorphological evidence also indicate northward extension of vegetation into modern-day desert areas, particularly in northern Africa, both in the mid-Holocene (Drake et al., 2011; Hely et al., 2014; Prentice et al., 2000) and during the maximum phase of the LIG (Castaneda et al., 2009; Hooghiemstra et al., 1992). Given the impact of increased woody cover on albedo and evapotranspiration, these vegetation changes should have profound impacts on the surface energy and water budgets and may help to explain mismatches between simulated and reconstructed high-latitude (Muschitiello et al., 2015) and monsoon climates (Braconnot et al., 1999; Claussen and Gayler, 1997; Pausata et al., 2016) in both time periods.

We propose a series of sensitivity experiments to explore the feedbacks between vegetation and climate in which vegetation cover in the high-latitudes is changed from tundra to boreal forest (experiment a) and the Sahara desert is (Lozhkin and Anderson, 1995) replaced by evergreen shrub to $25^{\circ} \mathrm{N}$ and savanna/steppe poleward of $25^{\circ} \mathrm{N}$ (experiment b). Ideally, these regional changes should be made separately in order to diagnose the interaction between high-latitude and low-latitude climates, and a third experiment could be made implementing both changes (experiment c). A more realistic simulation of the influence of mid-Holocene vegetation changes in the Sahara (experiment d) could be made using the gridded data set of land-surface conditions provided by Hoelzmann et al. (Hoelzmann et al., 1998), which gives proportions of specific vegetation types (steppe, savanna, xerophytic woods/scrub, tropical deciduous forest, and tropical montane evergreen forest), open water (lakes), and wetlands on a $1^{\circ}$ grid. This data set could also be used for a LIG sensitivity experiment, on the assumption that this provides a 
Clim. Past Discuss., doi:10.5194/cp-2016-106, 2016

Manuscript under review for journal Clim. Past

Published: 25 October 2016

(c) Author(s) 2016. CC-BY 3.0 License.

minimum estimate of the changes during that time (see e.g. Drake et al., 2011). The maps provided by Bigelow et al. (2003) provide more nuanced vegetation changes in high-latitude vegetation (experiment e), since they distinguish cold deciduous boreal forests from evergreen boreal forests and tundra. In each experiment, all other boundary conditions should be implemented as in the baseline midHolocene and lig $127 \mathrm{k}$ simulations.

Several modelling groups will be running simulations with models including dynamic vegetation, and this makes it possible to test the impact of the mid-Holocene vegetation changes on modern climate. For groups using dynamic vegetation, an additional sensitivity test is proposed in which the piControl simulation is run with the dynamic vegetation component is switched off and vegetation is prescribed using the Hoelzmann et al. vegetation map. Sensitivity experiments will also be required to characterize the uncertainties related to the prescription of dust fields in the midHolocene and LIG simulations, but it is difficult to anticipate the form of such experiments until the Tier 1 experiments are diagnosed. A first step could be to investigate the vegetation feedback on emission in simulations with interactive dust exploiting the vegetation sensitivity analyses.

\subsection{Sensitivity to Prescribed Ice Sheets}

The midHolocene and lig127k simulations will be run with prescribed modern ice sheets and paleogeography. However, it is highly likely that the Antarctic ice sheet was smaller than present by $\sim 127$ ka, most probably because of the disappearance of the WAIS, and that the Greenland ice sheet was reduced in extent compared to present. Given that only about 3-4 m sea level rise are covered by contributions from ocean thermal expansion (McKay et al., 2011), land based glaciers (Marzeion et al., 2012), and melting of the Greenland Ice Sheet (Dahl-Jensen et al., 2013; Masson-Delmotte et al., 2013), the remaining sea level rise is most likely to be linked to a mass loss from the Antarctic Ice Sheet. We propose a sensitivity experiment to test the impact of a smaller-than-present Antarctic ice sheet, using a reduced ice-sheet configuration obtained from off-line simulations with their own models or the model results such as those from DeConto and Pollard (2016) or Sutter et al. (2016). These authors used a dynamic ice

460 sheet model, forced with climate model output and calibrated to reproduce LIG sea-level estimates, to simulate the Antarctic ice sheet at $128 \mathrm{ka}$. All other boundary conditions should be implemented as in the baseline lig127k simulation. Additional simulations in which the Greenland ice sheet is configured to its minimum LIG extent are also of interest, using configurations obtained from off-line simulations, for example from ISMIP6.

\subsection{Freshwater Forcing}

465 Sensitivity to the H11 meltwater event during the early LIG. Heinrich layers in the North Atlantic, containing high concentrations of IRD, record multiple examples of prolonged iceberg discharge during the past $500 \mathrm{ka}$ (Hemming, 2004; Marino et al., 2015; McManus et al., 1999). Heinrich event 11 (H11) is a well-documented example that occurred from $\sim 135-128$ ka (Marino et al., 2015). The associated freshwater flux has been estimated as peaking at $\sim 0.3 \mathrm{~Sv}$ at $\sim 132.5 \mathrm{ka}$ and tapering off thereafter (Marino et al., 2015), and is broadly consistent with an estimate of $0.19 \mathrm{~Sv}$ at $130 \mathrm{ka}$ based on coral records (Carlson, 2008). There is also evidence of a rapid sea level rise associated with this meltwater pulse, estimated at $\sim 70 \mathrm{~m}$ or $28 \pm 8 \mathrm{~m} \mathrm{ka}^{-1}$ during the deglacial transition (Grant et al., 2012). 
Clim. Past Discuss., doi:10.5194/cp-2016-106, 2016

Manuscript under review for journal Clim. Past

Published: 25 October 2016

(c) Author(s) 2016. CC-BY 3.0 License.

Model simulations have shown that the freshwater forcing of H11, including its cessation, may be important for explaining the evolution of climate through the early part of the LIG (Goelzer et al., 2016b; Holden et al., 2010; Loutre et al., 2014; Stone et al., 2016). We propose a sensitivity experiment to examine the impact of the H11 event. The insolation anomalies at $130 \mathrm{ka}$ are similar to those at $127 \mathrm{ka}$. Therefore the experiment can be made by adding a persistent flux of $0.2 \mathrm{~Sv}$ to the North Atlantic between 50 and $70^{\circ} \mathrm{N}$ for 1000 years, with all other boundary conditions implemented as in the baseline lig127k simulation.

Sensitivity to the 8.2 ka fresh water event during the early Holocene. While the climate impact of the 8.2 ka event is well documented, the magnitude of the freshwater forcing and its duration are less well constrained. There are generally thought to be two components to the freshwater forcing in the early Holocene, a background flux from the Laurentide ice sheet (Hillaire-Marcel et al., 2007; Licciardi et al., 1999) and catastrophic flux from the drainage of Lake Agassiz (Barber et al., 1999; Clarke et al., 2004; Teller et al., 2002). The background flux is small (ca $0.13 \mathrm{~Sv}$ ) but persistent for several hundred years (Carlson et al., 2009; Carlson et al., 2008b; Clarke et al., 2009; HillaireMarcel et al., 2007). Lake Agassiz appears to have drained in several flood events of relatively short duration, but with an estimated total discharge into the Labrador Sea of ca 5 Sv (Andrews et al., 1999; Andrews et al., 1995; Clarke et al., 2009; Clarke et al., 2004; Ellison et al., 2006; Hillaire-Marcel et al., 2007; Kerwin, 1996; Lajeunesse and St-Onge, 2008; Lewis et al., 2012; Roy et al., 2011). The proposed sensitivity experiment uses the orbital, ice sheet, and GHG boundary conditions of an $8.5 \mathrm{ka}$ experiment and imposes a background freshwater flux of $0.05 \mathrm{~Sv}$ for 500 years and a single input of $2.5 \mathrm{~Sv}$ for one year. This freshwater flux is added to the Labrador Sea, but modeling groups can chose whether to add it uniformly over the whole of the Labrador Sea or only over part of the area. The simulation is then run until there is evidence for the recovery of the Atlantic Meridional Overturning Circulation (AMOC).

\subsection{Transient Holocene and LIG simulations}

495 Transient simulations provide an opportunity to examine the time-dependent evolution of climate in response to forcings and feedbacks. Transient simulations of the last deglaciation are a major focus in PMIP4 (Ivanovic et al., 2016). These simulations will be run for the period 21 to $9 \mathrm{ka}$ with time-varying orbital forcing, greenhouse gases, ice sheets and other geographical changes. The later part of this experiment is obviously of interest for comparison with the early Holocene experiments. However, we are also proposing transient simulations focusing on the

$500 \quad$ Holocene and the LIG.

Using the PMIP-CMIP6 midHolocene simulation as a starting point, we propose a transient simulation of the last 6000 years. In this simulation, both orbital parameters and GHGs will be changed following Berger and Loutre (1991) and ice-core measurements (as described in Section 2.2). Changes in paleotopography over the past 6 ka are small and, for simplicity and consistency with the midHolocene simulation, we propose using modern values throughout. Vegetation and aerosols will also be fixed at preindustrial values, except for groups running fully dynamic vegetation and/or aerosol models where the initial state of these components will be derived from their midHolocene simulation. Alternatively, some groups may start the Holocene transient simulation from the end of the 
Clim. Past Discuss., doi:10.5194/cp-2016-106, 2016

Manuscript under review for journal Clim. Past

Published: 25 October 2016

(c) Author(s) 2016. CC-BY 3.0 License.

last deglaciation experiment at $9 \mathrm{ka}$, incorporating changes in the evolution of ice sheets and paleotopography consistent with that experiment. A proposed LIG transient simulation will be run from 128 to $122 \mathrm{ka}$, using appropriate changes in orbital forcing but with all other boundary conditions specified as in the lig $127 k$ simulation. These simulations as well as simulations planned by some modeling groups with climate-ice sheet models will be important as input for addressing the role of coupling between climate and the ice sheets.

\section{Paleoenvironmental data and climate reconstructions for comparison to model simulations}

The ability to evaluate the realism of the core PMIP4-CMIP6 simulations and the various sensitivity experiments is central to PMIP. Some paleoenvironmental observations can be used for direct comparison with model outputs, including e.g. simulated water balance against lake-level reconstructions (e.g., Coe and Harrison, 2002) or simulated vegetation patterns against pollen-based vegetation reconstructions (e.g., Perez Sanz et al., 2014). Such qualitative comparisons are often adequate to evaluate simulations when, as is the case with regional climate changes in the mid-Holocene and LIG, the changes are large and regionally coherent (Harrison and Bartlein, 2012). There are also quantitative reconstructions of climate variables from a wide variety of archives. There are uncertainties associated with such reconstructions (Harrison et al., 2016), both statistical and resulting from an incomplete understanding of the climate controls on specific types of records, and these uncertainties need to be taken into account in comparisons with simulations. However, an increasing number of process-based models can be used to translate climate model outputs into explicit simulations of specific paleo-records (Emile-Geay and Tingley, 2016; Li et al., 2014; Thompson et al., 2011), allowing uncertainties in process understanding to be made explicit. Drawing on ongoing work for the LGM and the use of ocean biochemistry, tracer and isotopic modeling, efforts will be made to isolate key features of the ocean reconstructions that should be reproduced by climate models.

The major analytical focus for the Holocene experiments is on systematic benchmarking (Harrison et al., 2015) of the core midHolocene simulation, analysis of feedbacks, and elucidation of the relationship between mean climate state and interannual to centennial variability. Analysis of the midHolocene simulation and associated sensitivity experiments benefits from the fact that there has been a major focus on data synthesis for this time period (Bartlein et al., 2011; Bigelow and al., 2003; Daniau et al., 2012; Emile-Geay et al., 2016; Hessler et al., 2014; Kohfeld and Harrison, 2000; Leduc et al., 2010; Marchant et al., 2009; Marlon et al., 2013; Pickett et al., 2004; Prentice et al., 535 2000). Thus the number of records and spatial coverage of quantitative reconstructions are relatively extensive (Bartlein et al., 2011; Hessler et al., 2014). There are gaps in coverage from continental regions, particularly in the SH, but this situation is likely to improve in the near future (Flantua et al., 2015; Herbert and Harrison, 2016). Knowledge of ocean conditions during the mid-Holocene is poor and likely to remain so, in part because of incomplete understanding of the causes of differences between sea-surface temperature reconstructions based on 540 different biological groups and in part because the signal-to-noise ratio in the reconstructions is large due to other methodological uncertainties (Hessler et al., 2014; Jonkers and Kucera, 2015; Rosell-Mele and Prahl, 2013). There are several sources of information about short-term climate variability during the Holocene, including tree-ring records, spelothems, corals and molluscs. However, there are major gaps in data coverage from the tropical oceans 
Clim. Past Discuss., doi:10.5194/cp-2016-106, 2016

Manuscript under review for journal Clim. Past

Published: 25 October 2016

(c) Author(s) 2016. CC-BY 3.0 License.

that challenge our understanding of ENSO variability; the distribution of speleothem records is limited to karst areas; and few tropical trees show clear-cut seasonality in growth. More comprehensive syntheses of these data are needed, and there are major challenges in combining the different data sources to yield large-scale reconstructions of climate variability. It will also be necessary to develop appropriate methods to use these data for comparison with simulations, focusing on temporal statistics and teleconnection patterns (Emile-Geay et al., 2016; Emile-Geay and Tingley, 2016).

550

There are many individual records documenting the evolution of climate through the Holocene, including quantitative climate reconstructions (Wanner et al., 2008). Synthetic products have either focused on reconstructions of global temperature changes (Clark et al., 2012; Marcott et al., 2013; Shakun et al., 2012), or are available as geographically explicit data sets only for a limited number of climate variables in a few regions such as North America or Europe (Davis et al., 2003; Gajewski, 2015; Mauri et al., 2014; Viau and Gajewski, 2009; Viau et al., 2006). The only exception to this is the Global Lake Status Data Base (Kohfeld and Harrison, 2000), which provides qualitative estimates of the change in lake water balance through time globally. The reliability of global temperature estimates depends on the representativeness of the data included; this point has been made abundantly clear from comparisons of records of hemispheric temperature changes during the last millennium (Fernandez-Donado et al., 2013; Moberg, 2013). Currently available reconstructions of global temperature changes during the Holocene are heavily biased towards marine records, making it imperative that the reliability of these records is assessed using continental reconstructions (Davis et al., 2015; Liu et al., 2014). The lack of geographically explicit reconstructions for tropical regions and the SH would limit analysis of the Holocene transient simulations, but efforts are underway to improve this situation.

The LIG is the most suitable of the pre-Holocene interglacial periods as a focus in PMIP4-CMIP6 because of the relative wealth of data compared to earlier interglacial periods. However, there is an order of magnitude less information than for the Holocene, and there are larger uncertainties in dating of specific events. This means that the LIG data-model comparisons will focus on large-scale features, such as the strength of the high-latitude amplification of warming and the role of snow and sea-ice feedbacks in this warming. There will also be a major focus on the tropical water cycle. These analysis will exploit available datasets for the LIG which mostly document surface sea and air temperatures across the globe (Anderson et al., 2006; Bakker et al., 2013; Brewer et al., 2008; Capron et al., 2014; McKay et al., 2011; Turney and Jones, 2010) although recent efforts also synthesize reconstructions of sea ice changes (Esper and Gersonde, 2014; Sime et al., 2013), of the deep ocean circulation 575 (Oliver et al., 2010), and to a lesser extent the tropical hydrological cycle (Govin et al., 2014). In addition, several existing maps are reporting vegetation changes in the NH high latitudes (Bennike et al., 2001) and changes in lake area in the Sahara (Petit-Maire, 1999).

There are also syntheses of quantitative climate reconstructions for the LIG (Turney and Jones, 2008; McKay et al., 2011), which have been used for model evaluation (Lunt et al., 2013; Otto-Bliesner et al., 2013). The major 
Clim. Past Discuss., doi:10.5194/cp-2016-106, 2016

Manuscript under review for journal Clim. Past

Published: 25 October 2016

(c) Author(s) 2016. CC-BY 3.0 License.

limitation in using these two data sets for analysis of the $l i g 127 k$ simulations and associated sensitivity experiments is that they are compilations of information about the maximum warmth during the LIG. Given that warming was not synchronous globally (Bauch and Erlenkeuser, 2008; Cortese et al., 2007; Dahl-Jensen et al., 2013; Govin et al., 2012; Masson-Delmotte et al., 2010; Mor et al., 2012; Winsor et al., 2012), these syntheses do not represent a specific time slice. A more recent compilation by Capron et al. (2014) has used harmonized chronologies for ice and marine records to produce records of the change in high-latitude temperature compared to present for four 2000year long time slabs, and this approach has been expanded to include the fifth time slab (126-128 ka) for comparison with the lig127k simulation (Capron et al., 2016). However, even though these compilations are based on harmonized chronologies, dating uncertainties during the LIG can still be several thousand years depending on the type of archive and the dating methods (Govin et al., 2015). Furthermore, the different response scales of different components of the climate system means that records from the 126-128 ka time slab may still bear the imprint of the previous deglaciation (Fig. 1) (Capron et al., 2016). In any case, and as with the early Holocene experiments, the lig127k simulation will not solely reflect the insolation forcing. It is therefore recommended that data-model comparisons focus on using the temporal evolution of climate, as captured in the Capron et al. (2014) data sets, to assess the plausibility of the lig $127 k$ simulation.

\section{Conclusions}

The PMIP4-CMIP6 midHolocene and lig127k simulations provide an opportunity to examine the impact of two different changes in radiative forcing on climate at times when other forcings were relatively similar to present. Together with planned sensitivity experiments, this focus on the two interglacials will allow us to explore the role of

600 feedbacks in the climate system and to quantify their contribution to large-scale phenomena relevant to future projections such as land-sea contrast and high-latitude amplification of temperature changes. They will also allow us to address the implications of changes in forcing and feedbacks for the tropical circulation and monsoons - again an issue that is relevant to interpreting future projections. Given that both periods have been foci for model-model and data-model comparisons during previous phases of PMIP, a major focus during CMIP6 will be on evaluating the realism of the midHolocene and lig127k simulations using a wide range of paleoenvironmental data and paleoclimate reconstructions. This evaluation will be a direct out-of-sample test of the reliability of state-of-the-art models to simulate climate changes, and particularly the climate warming.

PMIP4 will collaborate with other CMIP6 projects (Kagayema et al., 2016, Table 3). The output from the lig127k simulation, for example, will be used to force standalone ice sheet experiments (ism-lig127k-std) in ISMIP6. This

610 will complement the suite of standalone ISMIP6 ice sheet experiments (Nowicki et al., 2016; http://www.climatecryosphere.org/activities/targeted/ismip6) for the recent past and future and will add to increase our understanding of the ice-sheet sensitivity to climate changes. The PMIP4-CMIP6 midHolocene and lig127k simulations, and associated sensitivity experiments, are also relevant to analyses of sea-ice feedbacks to climate in SIMIP (Notz et al., 2016) and to assessments of the role of dust forcing by AerChemMIP (Collins et al., 2016). Beyond CMIP6, the 615 planned PMIP4-CMIP6 interglacial simulations are relevant to the Grand Challenges set by the World Climate Research Programme (WCRP). Both the midHolocene and the lig127k simulations are relevant to the Grand 
Clim. Past Discuss., doi:10.5194/cp-2016-106, 2016

Manuscript under review for journal Clim. Past

Published: 25 October 2016

(c) Author(s) 2016. CC-BY 3.0 License.

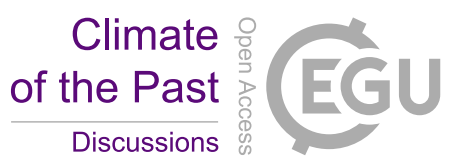

(c) (i)

Challenge "Clouds, Circulation and Climate Sensitivity", which has a major focus on the controls on the monsoon circulation. Also, the lig127k simulation is particularly relevant to the Grand Challenge "Melting Ice and Global Consequences", which addresses the stability of the ice sheets. Those simulations carried out with biogeochemical cycles enabled are relevant to the Grand Challenge "Carbon Feedbacks in the Climate System".

6 Acknowledgements. BLO-B acknowledges the funding by the U.S. National Science Foundation of the National Center for Atmospheric Research. PB, SPH, and FP acknowledge funding from the JPI-Belmont project "PAleaoConstraints on Monsoon Evolution and Dynamics (PACMEDY)" through their national funding agencies. SPH also acknowledges funding from the European Research Council for "GC2.0: Unlocking the past for a clearer future". FJ and CNA acknowledge support by the Swiss National Science Foundation. AH acknowledges funding support from the European Research Council under the Netherlands Earth System Science Centre (NESSC). EC is funded by the Dutch Ministry of Education, Culture European European Union's Seventh Framework Programme for research and Science (OCW) innovation under Grant nr. 024.002.001 the Marie Skłodowska-Curie(FP7/2007-2013)/ERC grant agreement no 600207. This work is a contribution to the PAGES/PMIP QUIGS Working Group. 
Clim. Past Discuss., doi:10.5194/cp-2016-106, 2016

Manuscript under review for journal Clim. Past

Published: 25 October 2016

(c) Author(s) 2016. CC-BY 3.0 License.

Albani, S., Mahowald, N. M., Murphy, L. N., Raiswell, R., Moore, J. K., Anderson, R. F., McGee, D., Bradtmiller, L. I., Delmonte, B., Hesse, P. P., and Mayewski, P. A.: Paleodust variability since the Last Glacial Maximum and implications for iron inputs to the ocean, Geophysical Research Letters, 43, 3944-3954, 2016.

Albani, S., Mahowald, N. M., Winckler, G., Anderson, R. F., Bradtmiller, L. I., Delmonte, B., Francois, R., Goman, M., Heavens, N. G., Hesse, P. P., Hovan, S. A., Kang, S. G., Kohfeld, K. E., Lu, H., Maggi, V., Mason, J. A., Mayewski, P. A., McGee, D., Miao, X., Otto-Bliesner, B. L., Perry, A. T., Pourmand, A., Roberts, H. M., Rosenbloom, N., Stevens, T., and Sun, J.: Twelve thousand years of dust: the Holocene global dust cycle constrained by natural archives, Climate of the Past, 11, 869-903, 2015.

Anderson, P., Bermike, O., Bigelow, N., Brigham-Grette, J., Duvall, M., Edwards, M., Frechette, B., Funder, S., Johnsen, S., Knies, J., Koerner, R., Lozhkin, A., Marshall, S., Matthiessen, J., Macdonald, G., Miller, G., Montoya, M., Muhs, D., Otto-Bliesner, B., Overpeck, J., Reeh, N., Sejrup, H. P., Spielhagen, R., Turner, C., Velichko, A., and Mem, C. A.-L. I. P.: Last Interglacial Arctic warmth confirms polar amplification of climate change, Quaternary Science Reviews, 25, 1383-1400, 2006.

645 palaeoceanography from high-resolution cores, Cartwright Saddle, Labrador Shelf, Canada, Journal of Quaternary Science, 14, 383-397, 1999.

Andrews, J. T., MacLean, B., Kerwin, M., Manley, W., Jennings, A. E., and Hall, F.: Final stages in the collapse of the Laurentide Ice Sheet, Hudson Strait, Canada, NWT: C-14 AMS dates, seismic stratigraphy, and magnetic susceptibility logs, Quaternary Science Reviews, 14, 983-1004, 1995.

650 Bakker, P., Stone, E. J., Charbit, S., Groger, M., Krebs-Kanzow, U., Ritz, S. P., Varma, V., Khon, V., Lunt, D. J., Mikolajewicz, U., Prange, M., Renssen, H., Schneider, B., and Schulz, M.: Last interglacial temperature evolution a model inter-comparison, Climate of the Past, 9, 605-619, 2013.

Barber, D. C., Dyke, A., Hillaire-Marcel, C., Jennings, A. E., Andrews, J. T., Kerwin, M. W., Bilodeau, G., McNeely, R., Southon, J., Morehead, M. D., and Gagnon, J. M.: Forcing of the cold event of 8,200 years ago by 655 catastrophic drainage of Laurentide lakes, Nature, 400, 344-348, 1999.

Bartlein, P. J., Harrison, S. P., Brewer, S., Connor, S., Davis, B. A. S., Gajewski, K., Guiot, J., Harrison-Prentice, T. I., Henderson, A., Peyron, O., Prentice, I. C., Scholze, M., Seppa, H., Shuman, B., Sugita, S., Thompson, R. S., Viau, A. E., Williams, J., and Wu, H.: Pollen-based continental climate reconstructions at 6 and 21 ka: a global synthesis, Climate Dynamics, 37, 775-802, 2011.

660 Bauch, H. A.: Interglacial climates and the Atlantic meridional overturning circulation: is there an Arctic controversy?, Quaternary Science Reviews, 63, 1-22, 2013.

Bauch, H. A. and Erlenkeuser, H.: A "critical" climatic evaluation of last interglacial (MIS 5e) records from the Norwegian Sea, Polar Research, 27, 135-151, 2008.

Bazin, L., Landais, A., Lemieux-Dudon, B., Kele, H. T. M., Veres, D., Parrenin, F., Martinerie, P., Ritz, C., Capron, E., Lipenkov, V., Loutre, M. F., Raynaud, D., Vinther, B., Svensson, A., Rasmussen, S. O., Severi, M., Blunier, T., Leuenberger, M., Fischer, H., Masson-Delmotte, V., Chappellaz, J., and Wolff, E.: An optimized multi-proxy, multisite Antarctic ice and gas orbital chronology (AICC2012): 120-800 ka, Climate of the Past, 9, 1715-1731, 2013.

Bennike, O., Bolshiyanov, D., Dowdeswell, J., Elverhoi, A., Geirsdottir, A., Hicks, S., Hubberton, H., Ingolfsson, O., Miller, G., and Members, C. P.: Holocene paleoclimate data from the Arctic: testing models of global climate change, Quaternary Science Reviews, 20, 1275-1287, 2001.

Bereiter, B., Eggleston, S., Schmitt, J., Nehrbass-Ahles, C., Stocker, T. F., Fischer, H., Kipfstuhl, S., and Chappellaz, J.: Revision of the EPICA Dome C CO2 record from 800 to $600 \mathrm{kyr}$ before present, Geophysical Research Letters, 42, 542-549, 2015.

675 Bigelow, N. H. and al., e.: Climate change and Arctic ecosystems: 1. Vegetation changes north doi:8110.1029/2002JD002558, 2003.

Blunier, T., Chappellaz, J., Schwander, J., Stauffer, B., and Raynaud, D.: Variations in atmospheric methane concentration during the Holocene epoch, Nature, 374, 46-49, 1995. 
Clim. Past Discuss., doi:10.5194/cp-2016-106, 2016

Manuscript under review for journal Clim. Past

Published: 25 October 2016

(c) Author(s) 2016. CC-BY 3.0 License.

Braconnot, P., Harrison, S. P., Kageyama, M., Bartlein, P. J., Masson-Delmotte, V., Abe-Ouchi, A., Otto-Bliesner, B., and Zhao, Y.: Evaluation of climate models using palaeoclimatic data, Nat Clim Change, 2, 417-424, 2012.

Braconnot, P., Joussaume, S., Marti, O., and de Noblet, N.: Synergistic feedbacks from ocean and vegetation on the African monsoon response to mid-Holocene insolation, Geophysical Research Letters, 26, 2481-2484, 1999.

Braconnot, P., Marzin, C., Gregoire, L., Mosquet, E., and Marti, O.: Monsoon response to changes in Earth's orbital parameters: comparisons between simulations of the Eemian and of the Holocene, Climate of the Past, 4, 281-294, 2008.

Braconnot, P., Otto-Bliesner, B., Harrison, S., Joussaume, S., Peterchmitt, J. Y., Abe-Ouchi, A., Crucifix, M., Driesschaert, E., Fichefet, T., Hewitt, C. D., Kageyama, M., Kitoh, A., Loutre, M. F., Marti, O., Merkel, U., Ramstein, G., Valdes, P., Weber, L., Yu, Y., and Zhao, Y.: Results of PMIP2 coupled simulations of the MidHolocene and Last Glacial Maximum - Part 2: feedbacks with emphasis on the location of the ITCZ and mid- and 690 high latitudes heat budget, Climate of the Past, 3, 279-296, 2007a.

Braconnot, P., Otto-Bliesner, B. L., Harrison, S. P., Joussaume, S., Peterschmitt, J. Y., and al., e.: Results of PMIP2 coupled simulations of the mid-Holocene and Last Glacial Maximum - Part 1: experiments and large-scale features, Climate of the Past, 3, 261-277, $2007 \mathrm{~b}$.

Brewer, S., Guiot, J., Sanchez-Goni, M. F., and Klotz, S.: The climate in Europe during the Eemian: a multi-method approach using pollen data, Quaternary Science Reviews, 27, 2303-2315, 2008.

Brook, E. J.: Methane Measurements from the GISP2 and Siple Dome Ice Cores, National Snow and Ice Data Center, Boulder, CO, USA, 2009.

Bruno, M. and Joos, F.: Terrestrial carbon storage during the past 200 years: A Monte Carlo analysis of CO2 data from ice core and atmospheric measurements, Glob. Biogeochem. Cycle, 11, 111-124, 1997.

700 Capron, E., Govin, A., Feng, R., Otto-Bliesner, B., and wolff, E. W.: A 126-128 ka high-latitude climate time slab to benchmark the Last Interglacial CMIP6/PMIP4 Tier 1 simulation, Quaternary Science Reviews, submitted., 2016.

Capron, E., Govin, A., Stone, E. J., Masson-Delmotte, V., Mulitza, S., Otto-Bliesner, B., Rasmussen, T. L., Sime, L. C., Waelbroeck, C., and Wolff, E. W.: Temporal and spatial structure of multi-millennial temperature changes at high latitudes during the Last Interglacial, Quaternary Science Reviews, 103, 116-133, 2014.

705 Carlson, A., Stoner, J. S., Donnelly, J. P., and Hillaire-Marcel, C.: Response of the southern Greenland Ice Sheet during the last two deglaciations, Geology, 36, 359-362, 2008a.

Carlson, A. E.: Why there was not a Younger Dryas-like event during the Penultimate Deglaciation, Quaternary Science Reviews, 27, 882-887, 2008.

Carlson, A. E., Clark, P. U., Haley, B. A., and Klinkhammer, G. P.: Routing of western Canadian Plains runoff during the 8.2 ka cold event, Geophysical Research Letters, 36, 2009.

Carlson, A. E., Legrande, A. N., Oppo, D. W., Came, R. E., Schmidt, G. A., Anslow, F. S., Licciardi, J. M., and Obbink, E. A.: Rapid early Holocene deglaciation of the Laurentide ice sheet, Nature Geoscience, 1, 620-624, 2008b.

Carlson, A. E. and Winsor, K.: Northern Hemisphere ice-sheet responses to past climate warming, Nature

715 Geoscience, 5, 607-613, 2012.

Carlson, A. E., Winsor, K., Ullman, D. J., Brook, E. J., Rood, D. H., Axford, Y., LeGrande, A. N., Anslow, F. S., and Sinclair, G.: Earliest Holocene south Greenland ice sheet retreat within its late Holocene extent, Geophysical Research Letters, 41, 5514-5521, 2014.

Carre, M., Sachs, J. P., Purca, S., Schauer, A. J., Braconnot, P., Falcon, R. A., Julien, M., and Lavallee, D.:

720 Holocene history of ENSO variance and asymmetry in the eastern tropical Pacific, Science, 345, 1045-1048, 2014.

Castaneda, I. S., Mulitza, S., Schefuss, E., dos Santos, R. A. L., Damste, J. S. S., and Schouten, S.: Wet phases in the Sahara/Sahel region and human migration patterns in North Africa, Proceedings of the National Academy of Sciences of the United States of America, 106, 20159-20163, 2009.

Chappellaz, J., Blunier, T., Kints, S., Dallenbach, A., Barnola, J. M., Schwander, J., Raynaud, D., and Stauffer, B.: 725 Changes in the atmospheric CH4 gradient between Greenland and Antarctica during the Holocene, J Geophys ResAtmos, 102, 15987-15997, 1997. 
Clim. Past Discuss., doi:10.5194/cp-2016-106, 2016

Manuscript under review for journal Clim. Past

Published: 25 October 2016

(c) Author(s) 2016. CC-BY 3.0 License.

Clark, C. D., Knight, J. K., and Gray, J. T.: Geomorphological reconstruction of the Labrador Sector of the Laurentide Ice Sheet, Quaternary Science Reviews, 19, 1343-1366, 2000.

Clark, P. U., Shakun, J. D., Baker, P. A., Bartlein, P. J., Brewer, S., Brook, E., Carlson, A. E., Cheng, H., Kaufman, D. S., Liu, Z. Y., Marchitto, T. M., Mix, A. C., Morrill, C., Otto-Bliesner, B. L., Pahnke, K., Russell, J. M., Whitlock, C., Adkins, J. F., Blois, J. L., Clark, J., Colman, S. M., Curry, W. B., Flower, B. P., He, F., Johnson, T. C., Lynch-Stieglitz, J., Markgraf, V., McManus, J., Mitrovica, J. X., Moreno, P. I., and Williams, J. W.: Global climate evolution during the last deglaciation, Proceedings of the National Academy of Sciences of the United States of America, 109, E1134-E1142, 2012.

735 Clarke, G. K. C., Bush, A. B. G., and Bush, J. W. M.: Freshwater Discharge, Sediment Transport, and Modeled Climate Impacts of the Final Drainage of Glacial Lake Agassiz, Journal of Climate, 22, 2161-2180, 2009.

Clarke, G. K. C., Leverington, D. W., Teller, J. T., and Dyke, A. S.: Paleohydraulics of the last outburst flood from glacial Lake Agassiz and the 8200 BP cold event, Quaternary Science Reviews, 23, 389-407, 2004.

Claussen, M. and Gayler, V.: The greening of the Sahara during the mid-Holocene: results of an interactive atmosphere-biome model, Global Ecology and Biogeography Letters, 6, 369-377, 1997.

Coe, M. T. and Harrison, S. P.: The water balance of northern Africa during the mid-Holocene: an evaluation of the 6 ka BP PMIP experiments, Climate Dynamics, 19, 155-166, 2002.

Collins, W. J., Lamarque, J.-F., Schulz, M., Boucher, O., Eyring, V., Hegglin, M. I., Maycock, A., Myhre, G., Prather, M., Shindell, D., and Smith, S. J.: AerChemMIP: Quantifying the effects of chemistry and aerosols in 745 CMIP6 Geosci. Model Dev. Discuss., 2016. 2016.

Colville, E. J., Carlson, A. E., Beard, B. L., Hatfield, R. G., Stoner, J. S., Reyes, A. V., and Ullman, D. J.: Sr-Nd-Pb Isotope Evidence for Ice-Sheet Presence on Southern Greenland During the Last Interglacial, Science, 333, 620-623, 2011.

Cortese, G., Abelmann, A., and Gersonde, R.: The last five glacial-interglacial transitions: A high-resolution 750 450,000-year record from the subantarctic Atlantic, Paleoceanography, 22, 2007.

Dahl-Jensen, D. and Albert, M. R. and Aldahan, A. and Azuma, N. and Balslev-Clausen, D. and Baumgartner, M. and Berggren, A. M. and Bigler, M. and Binder, T. and Blunier, T. and Bourgeois, J. C. and Brook, E. J. and Buchardt, S. L. and Buizert, C. and Capron, E. and Chappellaz, J. and Chung, J. and Clausen, H. B. and Cvijanovic, I. and Davies, S. M. and Ditlevsen, P. and Eicher, O. and Fischer, H. and Fisher, D. A. and Fleet, L. G. and Gfeller,

755 G. and Gkinis, V. and Gogineni, S. and Goto-Azuma, K. and Grinsted, A. and Gudlaugsdottir, H. and Guillevic, M. and Hansen, S. B. and Hansson, M. and Hirabayashi, M. and Hong, S. and Hur, S. D. and Huybrechts, P. and Hvidberg, C. S. and Iizuka, Y. and Jenk, T. and Johnsen, S. J. and Jones, T. R. and Jouzel, J. and Karlsson, N. B. and Kawamura, K. and Keegan, K. and Kettner, E. and Kipfstuhl, S. and Kjaer, H. A. and Koutnik, M. and Kuramoto, T. and Kohler, P. and Laepple, T. and Landais, A. and Langen, P. L. and Larsen, L. B. and Leuenberger,

760 D. and Leuenberger, M. and Leuschen, C. and Li, J. and Lipenkov, V. and Martinerie, P. and Maselli, O. J. and Masson-Delmotte, V. and McConnell, J. R. and Miller, H. and Mini, O. and Miyamoto, A. and Montagnat-Rentier, M. and Mulvaney, R. and Muscheler, R. and Orsi, A. J. and Paden, J. and Panton, C. and Pattyn, F. and Petit, J. R. and Pol, K. and Popp, T. and Possnert, G. and Prie, F. and Prokopiou, M. and Quiquet, A. and Rasmussen, S. O. and Raynaud, D. and Ren, J. and Reutenauer, C. and Ritz, C. and Rockmann, T. and Rosen, J. L. and Rubino, M. and

765 Rybak, O. and Samyn, D. and Sapart, C. J. and Schilt, A. and Schmidt, A. M. Z. and Schwander, J. and Schupbach, S. and Seierstad, I. and Severinghaus, J. P. and Sheldon, S. and Simonsen, S. B. and Sjolte, J. and Solgaard, A. M. and Sowers, T. and Sperlich, P. and Steen-Larsen, H. C. and Steffen, K. and Steffensen, J. P. and Steinhage, D. and Stocker, T. F. and Stowasser, C. and Sturevik, A. S. and Sturges, W. T. and Sveinbjornsdottir, A. and Svensson, A. and Tison, J. L. and Uetake, J. and Vallelonga, P. and van de Wal, R. S. W. and van der Wel, G. and Vaughn, B. H. and Vinther, B. and Waddington, E. and Wegner, A. and Weikusat, I. and White, J. W. C. and Wilhelms, F. and Winstrup, M. and Witrant, E. and Wolff, E. W. and Xiao, C. and Zheng, J. and Community, N.: Eemian interglacial reconstructed from a Greenland folded ice core, Nature, 493, 489-494, 2013.

Dallmeyer, A., Claussen, M., and Otto, J.: Contribution of oceanic and vegetation feedbacks to Holocene climate change in monsoonal Asia, Climate of the Past, 6, 195-218, 2010.

775 Daniau, A. L., Bartlein, P. J., Harrison, S. P., Prentice, I. C., Brewer, S., Friedlingstein, P., Harrison-Prentice, T. I., Inoue, J., Izumi, K., Marlon, J. R., Mooney, S., Power, M. J., Stevenson, J., Tinner, W., Andric, M., Atanassova, J., Behling, H., Black, M., Blarquez, O., Brown, K. J., Carcaillet, C., Colhoun, E. A., Colombaroli, D., Davis, B. A. S., D'Costa, D., Dodson, J., Dupont, L., Eshetu, Z., Gavin, D. G., Genries, A., Haberle, S., Hallett, D. J., Hope, G., 
Clim. Past Discuss., doi:10.5194/cp-2016-106, 2016

Manuscript under review for journal Clim. Past

Published: 25 October 2016

(c) Author(s) 2016. CC-BY 3.0 License.

Horn, S. P., Kassa, T. G., Katamura, F., Kennedy, L. M., Kershaw, P., Krivonogov, S., Long, C., Magri, D., Marinova, E., McKenzie, G. M., Moreno, P. I., Moss, P., Neumann, F. H., Norstrom, E., Paitre, C., Rius, D., Roberts, N., Robinson, G. S., Sasaki, N., Scott, L., Takahara, H., Terwilliger, V., Thevenon, F., Turner, R., Valsecchi, V. G., Vanniere, B., Walsh, M., Williams, N., and Zhang, Y.: Predictability of biomass burning in response to climate changes, Glob. Biogeochem. Cycle, 26, 12, 2012.

Davis, B. A. S., Brewer, S., Stevenson, A. C., Guiot, J., and Data, C.: The temperature of Europe during the Holocene reconstructed from pollen data, Quaternary Science Reviews, 22, 1701-1716, 2003.

Davis, B. A. S., Collins, P. M., and Kaplan, J. O.: The age and post-glacial development of the modern European vegetation: a plant functional approach based on pollen data, Vegetation History and Archaeobotany, 24, 303-317, 2015.

DeConto, R. M. and Pollard, D.: Contribution of Antarctica to past and future sea-level rise, Nature, 531, 591-597, 2016.

deMenocal, P., Ortiz, J., Guilderson, T., Adkins, J., Sarnthein, M., Baker, L., and Yarusinsky, M.: Abrupt onset and termination of the African Humid Period: rapid climate responses to gradual insolation forcing, Quaternary Science Reviews, 19, 347-361, 2000.

Drake, N. A., Blench, R. M., Armitage, S. J., Bristow, C. S., and White, K. H.: Ancient watercourses and

795 biogeography of the Sahara explain the peopling of the desert, Proceedings of the National Academy of Sciences of the United States of America, 108, 458-462, 2011.

Dufresne, J.-L. and co-authors: Climate change projections using the IPSL-CM5 Earth System Model: from CMIP3 to CMIP5, Climate Dynamics, 40, 2123-2165, 2013.

Dutton, A., Carlson, A. E., Long, A. J., Milne, G. A., Clark, P. U., DeConto, R., Horton, B. P., Rahmstorf, S., and

800 Raymo, M. E.: Sea-level rise due to polar ice-sheet mass loss during past warm periods, Science, 349, $2015 \mathrm{a}$.

Dutton, A., Webster, J. M., Zwartz, D., Lambeck, K., and Wohlfarth, B.: Tropical tales of polar ice: evidence of Last Interglacial polar ice sheet retreat recorded by fossil reefs of the granitic Seychelles islands, Quaternary Science Reviews, 107, 182-196, 2015 b.

Edwards, M. E., Hamilton, T. D., Elias, S. A., Bigelow, N. H., and Krumhardt, A. P.: Interglacial extension of the

805 boreal forest limit in the Noatak Valley, northwest Alaska: Evidence from an exhumed river-cut bluff and debris apron, Arctic, Antarctic, and Alpine Research, 35, 460-468, 2003.

Ellison, C. R. W., Chapman, M. R., and Hall, I. R.: Surface and deep ocean interactions during the cold climate event 8200 years ago, Science, 312, 1929-1932, 2006.

Emile-Geay, J., Cobb, K. M., Carre, M., Braconnot, P., Leloup, J., Zhou, Y., Harrison, S. P., Correge, T., McGregor,

810 H. V., Collins, M., Driscoll, R., Elliot, M., Schneider, B., and Tudhope, A.: Links between tropical Pacific seasonal, interannual and orbital variability during the Holocene, Nature Geoscience, 9, 168-+, 2016.

Emile-Geay, J. and Tingley, M.: Inferring climate variability from nonlinear proxies: application to palaeo-ENSO studies, Climate of the Past, 12, 31-50, 2016.

Enting, I. G.: On the use of smoothing splines to filter $\mathrm{CO}_{2}$ data, J Geophys Res-Atmos, 92, 10977-10984, 1987.

815 EPICA Community Members: One-to-one coupling of glacial climate variability in Greenland and Antarctica, Nature, 444, 195-198, 2006.

Esper, O. and Gersonde, R.: New tools for the reconstruction of Pleistocene Antarctic sea ice, Paleogeogr. Paleoclimatol. Paleoecol., 399, 260-283, 2014.

Eyring, V., Bony, S., Meehl, G. A., Senior, C. A., Stevens, B., Stouffer, R. J., and Taylor, K. E.: Overview of the

820 Coupled Model Intercomparison Project Phase 6 (CMIP6) experimental design and organization, Geosci. Model Dev., 9, 1937-1958, 2016.

Fernandez-Donado, L., Gonzalez-Rouco, J. F., Raible, C. C., Ammann, C. M., Barriopedro, D., Garcia-Bustamante, E., Jungclaus, J. H., Lorenz, S. J., Luterbacher, J., Phipps, S. J., Servonnat, J., Swingedouw, D., Tett, S. F. B., Wagner, S., Yiou, P., and Zorita, E.: Large-scale temperature response to external forcing in simulations and 825 reconstructions of the last millennium, Climate of the Past, 9, 393-421, 2013.

Flantua, S. G. A., Hooghiemstra, H., Grimm, E. C., Behling, H., Bush, M. B., Gonzalez-Arango, C., Gosling, W. D., Ledru, M. P., Lozano-Garcia, S., Maldonado, A., Prieto, A. R., Rull, V., and Van Boxel, J. H.: Updated site compilation of the Latin American Pollen Database, Rev. Palaeobot. Palynology, 223, 104-115, 2015. 
Clim. Past Discuss., doi:10.5194/cp-2016-106, 2016

Manuscript under review for journal Clim. Past

Published: 25 October 2016

(c) Author(s) 2016. CC-BY 3.0 License.

Flato, G., Marotzke, J., Abiodun, B., Braconnot, P., Chou, S. C., Collins, W., Cox, P., Driouech, F., Emori, S., Eyring, V., Forest, C., Gleckler, P., Guilyardi, E., Jakob, C., Kattsov, V., Reason, C., and Rummukainen, M.: Evaluation of Climate Models. In: Climate Change 2013: The Physical Science Basis. Contribution of Working Group I to the Fifth Assessment Report of the Intergovernmental Panel on Climate Change, Stocker, T. F., Qin, D., Plattner, G.-K., Tignor, M., Allen, S. K., Boschung, J., Nauels, A., Xia, Y., Bex, V., and Midgley, P. M. (Eds.), Cambridge University Press, Cambridge, United Kingdom and New York, NY, USA, 2013.

835 Fluckiger, J., Monnin, E., Stauffer, B., Schwander, J., Stocker, T. F., Chappellaz, J., Raynaud, D., and Barnola, J. M.: High-resolution Holocene $\mathrm{N}_{2} \mathrm{O}$ ice core record and its relationship with $\mathrm{CH}_{4}$ and $\mathrm{CO}_{2}$, Glob. Biogeochem. Cycle, 16, 2002.

Folland, C. I., Karl, T. R., Christy, J. R., Clarke, R. A., Gruza, G. V., Jouzel, J., Mann, M. E., Oerlemans, J., Salinger, M. J., and Wang, S.-W.: Observed climate variability and change. In: Climate Change 2001: The scientific basis. Contribution of Working Group I to the Third Assessment Report of the Intergovernmental Panel on Climate Change, Houghton, J. T., Ding, Y., Griggs, D. J., Noguer, M., van der Linden, P. J., Dai, X., Maskell, K., and Johnson, C. A. (Eds.), Cambridge University Press, Cambridge, United Kingdom and New York, NY, 2001.

Gajewski, K.: Impact of Holocene climate variability on Arctic vegetation, Global Planet Change, 133, 272-287, 2015.

845 Goelzer, H., Huybrechts, P., Loutre, M.-F., and Fichefet, T.: Impact of ice sheet meltwater fluxes on the climate evolution at the onset of the Last Interglacial, Clim. Past, 12, 1721-1737, 2016a.

Goelzer, H., Huybrechts, P., Loutre, M. F., and Fichefet, T.: Impact of ice sheet meltwater fluxes on the climate evolution at the onset of the Last Interglacial, Clim. Past, 12, 1721-1727, $2016 \mathrm{~b}$.

Goni, M. F. S., Loutre, M. F., Crucifx, M., Peyron, O., Santos, L., Duprat, J., Malaize, B., Turon, J. L., and

850 Peypouquet, J. P.: Increasing vegetation and climate gradient in Western Europe over the Last Glacial Inception (122-110 ka): data-model comparison, Earth Planet. Sci. Lett., 231, 111-130, 2005.

Govin, A., Braconnot, P., Capron, E., Cortijo, E., Duplessy, J. C., Jansen, E., Labeyrie, L., Landais, A., Marti, O., Michel, E., Mosquet, E., Risebrobakken, B., Swingedouw, D., and Waelbroeck, C.: Persistent influence of ice sheet melting on high northern latitude climate during the early Last Interglacial, Climate of the Past, 8, 483-507, 2012.

855 Govin, A., Varma, V., and Prange, M.: Astronomically forced variations in western African rainfall ( 21 N-20 S) during the Last Interglacial period, Geophysical Research Letters, 41, 2117-2125, 2014.

Grant, K. M., Rohling, E. J., Bar-Matthews, M., Ayalon, A., Medina-Elizalde, M., Ramsey, C. B., Satow, C., and Roberts, A. P.: Rapid coupling between ice volume and polar temperature over the past 150,000 years, Nature, 491, 744-747, 2012.

860 Harrison, S. P. and Bartlein, P. J.: Records from the past, lessons for the future: what the palaeo-record implies about mechanisms of global change. In: The Future of the World's Climates, McGuffie, A. H.-S. a. K. (Ed.), 2012.

Harrison, S. P., Bartlein, P. J., Brewer, S., Prentice, I. C., Boyd, M., Hessler, I., Holmgren, K., Izumi, K., and Willis, K.: Climate model benchmarking with glacial and mid-Holocene climates, Climate Dynamics, 43, 671-688, 2014.

Harrison, S. P., Bartlein, P. J., Izumi, K., Li, G., Annan, J., Hargreaves, J., Braconnot, P., and Kageyama, M.:

865 Evaluation of CMIP5 palaeo-simulations to improve climate projections, Nat Clim Change, 5, 735-743, 2015.

Harrison, S. P., Jolly, D., Laarif, F., Abe-Ouchi, A., Dong, B., Herterich, K., Hewitt, C., Joussaume, S., Kutzbach, J. E., Mitchell, J., De Noblet, N., and Valdes, P.: Intercomparison of simulated global vegetation distributions in response to 6 kyr BP orbital forcing, Journal of Climate, 11, 2721-2742, 1998.

Hegerl, G. C., Zwiers, F. W., Braconnot, P., Gillett, N. P., Luo, Y., Marengo Orsini, J. A., Nicholls, N., Penner, J.

870 E., and Stott, P., A.: Understanding and Attributing Climate Change. In: Climate Change 2007: The Physical Science Basis. Contribution of Working Group I to the Fourth Assessment Report of the Intergovernmental Panel on Climate Change, Solomon, S., Qin, D., Manning, M., Chen, Z., Marquis, M., Averyt, K. B., Tignor, M., and Miller, H. L. (Eds.), Cambridge University Press, Cambridge, United Kingdom and New York, NY, USA, 2007.

Hely, C., Lezine, A. M., and Contributors, A. P. D.: Holocene changes in African vegetation: tradeoff between 875 climate and water availability, Climate of the Past, 10, 681-686, 2014.

Hemming, S. R.: Heinrich events: Massive late pleistocene detritus layers of the North Atlantic and their global climate imprint, Reviews of Geophysics, 42, 2004. 
Clim. Past Discuss., doi:10.5194/cp-2016-106, 2016

Manuscript under review for journal Clim. Past

Published: 25 October 2016

(c) Author(s) 2016. CC-BY 3.0 License.

Herbert, A. V. and Harrison, S. P.: Evaluation of a modern-analogue methodology for reconstructing Australian palaeoclimate from pollen, Rev. Palaeobot. Palynology, 226, 65-77, 2016.

880 Herrington, A. R. and Poulsen, C. J.: Terminating the Last Interglacial: The Role of Ice Sheet-Climate Feedbacks in a GCM Asynchronously Coupled to an Ice Sheet Model, Journal of Climate, 25, 1871-1882, 2012.

Hessler, I., Harrison, S. P., Kucera, M., Waelbroeck, C., Chen, M. T., Anderson, C., de Vernal, A., Frechette, B., Cloke-Hayes, A., Leduc, G., and Londeix, L.: Implication of methodological uncertainties for mid-Holocene sea surface temperature reconstructions, Climate of the Past, 10, 2237-2252, 2014.

885 Hillaire-Marcel, C., de Vernal, A., and Piper, D. J. W.: Lake Agassiz final drainage event in the northwest North Atlantic, Geophysical Research Letters, 34, 2007.

Hoelzmann, P., Jolly, D., Harrison, S. P., Laarif, F., Bonnefille, R., and Pachur, H. J.: Mid-Holocene land-surface conditions in northern Africa and the Arabian Peninsula: A data set for the analysis of biogeophysical feedbacks in the climate system, Glob. Biogeochem. Cycle, 12, 35-51, 1998.

890 Holden, P. B., Edwards, N. R., Wolff, E. W., Lang, N. J., Singarayer, J. S., Valdes, P. J., and Stocker, T. F.: Interhemispheric coupling, the West Antarctic Ice Sheet and warm Antarctic interglacials, Climate of the Past, 6, 431-443, 2010.

Hooghiemstra, H., Stalling, H., Agwu, C. O. C., and Dupont, L. M.: Vegetational and climatic changes at the northern fringe of the sahara 250,000-5000 years bp - evidence from 4 marine pollen records located between 895 Portugal and the Canary-Islands, Rev. Palaeobot. Palynology, 74, 1-53, 1992.

Ivanovic, R. F., Gregoire, L. J., Kageyama, M., Roche, D. M., Valdes, P. J., Burke, A., Drummonnd, R., Peltier, W. R., and Tarasov, L.: Transient climate simulations of the deglaciation 21-9 thousand years before present (version 1) - PMIP4 Core experiment design and boundary conditions, Geosci. Model Dev., 9, 2563-2587, 2016.

Jansen, E., Overpeck, J., Briffa, K. R., Duplessy, J. C., Joos, F., Masson-Delmotte, V., Olago, D., Otto-Bliesner, B.,

900 Peltier, W. R., Rahmstorf, S., Ramesh, R., Raynaud, D., Rind, D., Solomina, O., Villalba, R., and Zhang, D.: Palaeoclimate. In: Climate Change 2007: The Physical Science Basis. Contribution of Working Group I to the Fourth Assessment Report of the Intergovernmental Panel on Climate Change, Solomon, S., Qin, D., Manning, M., Chen, Z., Marquis, M., Averyt, K. B., Tignor, M., and Miller, H. L. (Eds.), Cambridge University Press, Cambridge, United Kingdom and New York, NY, USA, 2007.

905 Jochum, M., Jahn, A., Peacock, S., Bailey, D. A., Fasullo, J. T., Kay, J., Levis, S., and Otto-Bliesner, B.: True to Milankovitch: Glacial Inception in the New Community Climate System Model, Journal of Climate, 25, 2226-2239, 2012.

Jonkers, L. and Kucera, M.: Global analysis of seasonality in the shell flux of extant planktonic Foraminifera, Biogeosciences, 12, 2207-2226, 2015.

910 Joos, F. and Spahni, R.: Rates of change in natural and anthropogenic radiative forcing over the past 20,000 years, Proceedings of the National Academy of Sciences of the United States of America, 105, 1425-1430, 2008.

Joussaume, S. and Braconnot, P.: Sensitivity of paleoclimate simulation results to season definitions, J Geophys Res-Atmos, 102, 1943-1956, 1997.

Joussaume, S. and Taylor, K. E.: Status of the Paleoclimate Modeling Intercomparison Project, in: Proceedings of 915 the first international AMIP scientific conference, Monterey, USA, 425-430 pp., 1995.

Joussaume, S., Taylor, K. E., Braconnot, P., Mitchell, J. F. B., Kutzbach, J. E., Harrison, S. P., Prentice, I. C., Broccoli, A. J., Abe-Ouchi, A., Bartlein, P. J., Bonfils, C., Dong, B., Guiot, J., Herterich, K., Hewitt, C. D., Jolly, D., Kim, J. W., Kislov, A., Kitoh, A., Loutre, M. F., Masson, V., McAvaney, B., McFarlane, N., de Noblet, N., Peltier, W. R., Peterschmitt, J. Y., Pollard, D., Rind, D., Royer, J. F., Schlesinger, M. E., Syktus, J., Thompson, S., 920 Valdes, P., Vettoretti, G., Webb, R. S., and Wyputta, U.: Monsoon changes for 6000 years ago: Results of 18 simulations from the Paleoclimate Modeling Intercomparison Project (PMIP), Geophysical Research Letters, 26, 859-862, 1999.

Kageyama, M. et al.: PMIP4-CMIP6: the contribution of the Paleoclimate Modelling Intercomparison Project to CMIP6, Geosci. Model Dev., 2016.

925 Kerwin, M. W.: A regional stratigraphic isochron (ca 8000 C-14 yr BP) from final deglaciation of Hudson Strait, Quat. Res., 46, 89-98, 1996. 
Clim. Past Discuss., doi:10.5194/cp-2016-106, 2016

Manuscript under review for journal Clim. Past

Published: 25 October 2016

(c) Author(s) 2016. CC-BY 3.0 License.

Kohfeld, K. and Harrison, S. P.: How well can we simulate past climates? Evaluating the models using global palaeoenvironmental datasets, Quaternary Science Reviews, 19, 321-346, 2000.

Konare, A., Zakey, A. S., Solmon, F., Giorgi, F., Rauscher, S., Ibrah, S., and Bi, X.: A regional climate modeling study of the effect of desert dust on the West African monsoon, J Geophys Res-Atmos, 113, 2008.

Krinner, G., Boucher, O., and Balkanski, Y.: Ice-free glacial northern Asia due to dust deposition on snow, Climate Dynamics, 27, 613-625, 2006.

Kutzbach, J. E. and Gallimore, R. G.: Sensitivity of a coupled atmosphere mixed layer ocean model to changes in orbital forcing at 9000 years BP, J Geophys Res-Atmos, 93, 803-821, 1988.

935 Kutzbach, J. E. and Street-Perrott, F. A.: Milankovitch forcing of fluctuations in the level of tropical lakes from 18 to 0 kyr BP, Nature, 317, 130-134, 1985.

Lajeunesse, P. and St-Onge, G.: The subglacial origin of the lake Agassiz-Ojibway final outburst flood, Nature Geoscience, 1, 184-188, 2008.

Larsen, N. K., Kjaer, K. H., Lecavalier, B., Bjork, A. A., Colding, S., Huybrechts, P., Jakobsen, K. E., Kjeldsen, K. K., Knudsen, K. L., Odgaard, B. V., and Olsen, J.: The response of the southern Greenland ice sheet to the Holocene thermal maximum, Geology, 43, 291-294, 2015.

Lecavalier, B. S. and Markle, B. R.: Developments in ice core research on past climate change, EOS, 97, 2016.

Leduc, G., Schneider, R., Kim, J. H., and Lohmann, G.: Holocene and Eemian sea surface temperature trends as revealed by alkenone and $\mathrm{Mg} / \mathrm{Ca}$ paleothermometry, Quaternary Science Reviews, 29, 989-1004, 2010.

945 Lewis, C. F. M., Miller, A. A. L., Levac, E., Piper, D. J. W., and Sonnichsen, G. V.: Lake Agassiz outburst age and routing by Labrador Current and the $8.2 \mathrm{cal}$ ka cold event, Quaternary International, 260, 83-97, 2012.

Lezine, A. M., Zheng, W., Braconnot, P., and Krinner, G.: Late Holocene plant and climate evolution at Lake Yoa, northern Chad: pollen data and climate simulations, Climate of the Past, 7, 1351-1362, 2011.

950 production, carbon allocation, and growth, Biogeosciences, 11, 6711-6724, 2014.

Licciardi, J. M., Teller, J. T., and Clark, P. U.: Freshwater Routing by the Laurentide Ice Sheet During the Last Deglaciation. In: Mechanisms of Global Climate Change at Millennial Time Scales Geophysical Monograph, P. U. Clark, R. S. W. a. L. D. K. (Ed.), 1999.

955 Quaternary International, 10-12, 9-28, 1991.

Liu, Z. Y., Zhu, J., Rosenthal, Y., Zhang, X., Otto-Bliesner, B. L., Timmermann, A., Smith, R. S., Lohmann, G., Zheng, W. P., and Timm, O. E.: The Holocene temperature conundrum, Proceedings of the National Academy of Sciences of the United States of America, 111, E3501-E3505, 2014.

Loulergue, L., Schilt, A., Spahni, R., Masson-Delmotte, V., Blunier, T., Lemieux, B., Barnola, J. M., Raynaud, D.,

960 Stocker, T. F., and Chappellaz, J.: Orbital and millennial-scale features of atmospheric $\mathrm{CH}_{4}$ over the past 800,000 years, Nature, 453, 383-386, 2008.

Loutre, M. F., Fichefet, T., Goosse, H., Huybrechts, P., Goelzer, H., and Capron, E.: Factors controlling the last interglacial climate as simulated by LOVECLIM1.3, Climate of the Past, 10, 1541-1565, 2014.

Lozhkin, A. V. and Anderson, P. M.: The last interglaciation in northeast Siberia, Quat. Res., 43, 147-158, 1995.

965 Luan, Y. H., Braconnot, P., Yu, Y. Q., and Zheng, W. P.: Tropical Pacific mean state and ENSO changes: sensitivity to freshwater flux and remnant ice sheets at $9.5 \mathrm{ka}$ BP, Climate Dynamics, 44, 661-678, 2015.

Marchant, R., Cleef, A., Harrison, S. P., Hooghiemstra, H., Markgraf, V., van Boxel, J., Ager, T., Almeida, L., Anderson, R., Baied, C., Behling, H., Berrio, J. C., Burbridge, R., Bjorck, S., Byrne, R., Bush, M., Duivenvoorden, J., Flenley, J., De Oliveira, P., van Geel, B., Graf, K., Gosling, W. D., Harbele, S., van der Hammen, T., Hansen, B.,

970 Horn, S., Kuhry, P., Ledru, M. P., Mayle, F., Leyden, B., Lozano-Garcia, S., Melief, A. M., Moreno, P., Moar, N. T., Prieto, A., van Reenen, G., Salgado-Labouriau, M., Schabitz, F., Schreve-Brinkman, E. J., and Wille, M.: Pollenbased biome reconstructions for Latin America at 0,6000 and 18000 radiocarbon years ago, Climate of the Past, 5, 725-767, 2009.

Marcott, S. A., Shakun, J. D., Clark, P. U., and Mix, A. C.: A Reconstruction of Regional and Global Temperature 
Clim. Past Discuss., doi:10.5194/cp-2016-106, 2016

Manuscript under review for journal Clim. Past

Published: 25 October 2016

(c) Author(s) 2016. CC-BY 3.0 License.

Marino, G., Rohling, E. J., Rodriguez-Sanz, L., Grant, K. M., Heslop, D., Roberts, A. P., Stanford, J. D., and Yu, J.: Bipolar seesaw control on last interglacial sea level, Nature, 522, 197-+, 2015.

Marlon, J. R., Bartlein, P. J., Daniau, A. L., Harrison, S. P., Maezumi, S. Y., Power, M. J., Tinner, W., and Vanniere, B.: Global biomass burning: a synthesis and review of Holocene paleofire records and their controls, Quaternary Science Reviews, 65, 5-25, 2013.

Marzeion, B., Jarosch, A. H., and Hofer, M.: Past and future sea-level change from the surface mass balance of glaciers, Cryosphere, 6, 1295-1322, 2012.

Marzin, C., Braconnot, P., and Kageyama, M.: Relative impacts of insolation changes, meltwater fluxes and ice sheets on African and Asian monsoons during the Holocene, Climate Dynamics, 41, 2267-2286, 2013.

985 Masson-Delmotte, V., Schulz, M., Abe-Ouchi, A., Beer, J., Ganopolski, A., Gonzalez Rouco, J., Jansen, E., Lambeck, K., Luterbacher, J., Naish, T., Osborn, T., Otto-Bliesner, B., Quinn, T., Ramesh, R., Rojas, M., Shao, X., and Timmermann, A.: Information from paleoclimate archvies. In: The Physical Science Basis. Contribution of Working Group I to the Fifth Assessment Report of the Intergovernmental Panel on Climate Change, Stocker, T. F., Qin, D., Plattner, G.-K., Tignor, M., Allen, S. K., Boschung, J., Nauels, A., Xia, Y., Bex, V., and Midgley, P. M.

990 (Eds.), Cambridge University Press, Cambridge, United Kingdom and New York, NY, USA, 2013.

Masson-Delmotte, V., Stenni, B., Blunier, T., Cattani, O., Chappellaz, J., Cheng, H., Dreyfus, G., Edwards, R. L., Falourd, S., Govin, A., Kawamura, K., Johnsen, S. J., Jouzel, J., Landais, A., Lemieux-Dudon, B., Lourantou, A., Marshall, G., Minster, B., Mudelsee, M., Pol, K., Rothlisberger, R., Selmo, E., and Waelbroeck, C.: Abrupt change of Antarctic moisture origin at the end of Termination II, Proceedings of the National Academy of Sciences of the 995 United States of America, 107, 12091-12094, 2010.

Mauri, A., Davis, B. A. S., Collins, P. M., and Kaplan, J. O.: The influence of atmospheric circulation on the midHolocene climate of Europe: a data-model comparison, Climate of the Past, 10, 1925-1938, 2014.

McKay, N. P., Overpeck, J. T., and Otto-Bliesner, B. L.: The role of ocean thermal expansion in Last Interglacial sea level rise, Geophysical Research Letters, 38, 2011.

1000 McKay, R., Naish, T., Powell, R., Barrett, P., Scherer, R., Talarico, F., Kyle, P., Monien, D., Kuhn, G., Jackolski, C., and Williams, T.: Pleistocene variability of Antarctic Ice Sheet extent in the Ross Embayment, Quaternary Science Reviews, 34, 93-112, 2012.

McManus, J. F., Oppo, D. W., and Cullen, J. L.: A 0.5-million-year record of millennial-scale climate variability in the North Atlantic, Science, 283, 971-975, 1999.

1005 Mercer, J. H.: West Antarctic Ice Sheet And CO2 greenhouse effect - threat of disaster, Nature, 271, 321-325, 1978.

Miller, R. L., Perlwitz, J., and Tegen, I.: Feedback upon dust emission by dust radiative forcing through the planetary boundary layer, J Geophys Res-Atmos, 109, 2004.

Mitchell, L., Brook, E., Lee, J. E., Buizert, C., and Sowers, T.: Constraints on the Late Holocene Anthropogenic Contribution to the Atmospheric Methane Budget, Science, 342, 964-966, 2013.

1010 Moberg, A.: Comparisons of simulated and observed Northern Hemisphere temperature variations during the past millennium - selected lessons learned and problems encountered, Tellus Series B-Chemical and Physical Meteorology, 65, 2013.

Monnin, E., Indermuhle, A., Dallenbach, A., Fluckiger, J., Stauffer, B., Stocker, T. F., Raynaud, D., and Barnola, J. M.: Atmospheric $\mathrm{CO}_{2}$ concentrations over the last glacial termination, Science, 291, 112-114, 2001.

1015 Monnin, E., Steig, E. J., Siegenthaler, U., Kawamura, K., Schwander, J., Stauffer, B., Stocker, T. F., Morse, D. L., Barnola, J. M., Bellier, B., Raynaud, D., and Fischer, H.: Evidence for substantial accumulation rate variability in Antarctica during the Holocene, through synchronization of CO2 in the Taylor Dome, Dome C and DML ice cores, Earth Planet. Sci. Lett., 224, 45-54, 2004.

Mor, A. S., Yam, R., Bianchi, C., Kunz-Pirrung, M., Gersonde, R., and Shemesh, A.: Variable sequence of events 1020 during the past seven terminations in two deep-sea cores from the Southern Ocean, Quat. Res., 77, 317-325, 2012.

Muschitiello, F., Zhang, Q., Sundqvist, H. S., Davies, F. J., and Renssen, H.: Arctic climate response to the termination of the African Humid Period, Quaternary Science Reviews, 125, 91-97, 2015.

Myhre, G., Highwood, E. J., Shine, K. P., and Stordal, F.: New estimates of radiative forcing due to well mixed greenhouse gases, Geophysical Research Letters, 25, 2715-2718, 1998. 
Clim. Past Discuss., doi:10.5194/cp-2016-106, 2016

Manuscript under review for journal Clim. Past

Published: 25 October 2016

(c) Author(s) 2016. CC-BY 3.0 License. Laurentide outburst flooding event during the last interglacial period, Nature Geoscience, 5, 901-904, 2012.

Notz, D., Jahn, A., Holland, M., Hunke, E., Massonnet, F., Stroeve, J., Tremblay, B., and Vancoppenolle, M.: The CMIP6 Sea-Ice Model Intercomparison Project (SIMIP): understanding sea ice through climate-model simulations, Geosci. Model Dev., 9, 3427-3446, 2016.

1030 Nowicki, S. M. J., Payne, T., Larour, E., Seroussi, H., Goelzer, H., Lipscomb, W., Gregory, J., Abe-Ouchi, A., and Shepherd, A.: Ice Sheet Model Intercomparison Project (ISMIP6) contribution to CMIP6, Geosci. Model Dev. Discuss., doi: doi:10.5194/gmd-2016-105, 2016.

Oliver, K. I. C., Hoogakker, B. A. A., Crowhurst, S., Henderson, G. M., Rickaby, R. E. M., Edwards, N. R., and Elderfield, H.: A synthesis of marine sediment core delta C-13 data over the last 150000 years, Climate of the Past, $10356,645-673,2010$.

Otto, J., Raddatz, T., Claussen, M., Brovkin, V., and Gayler, V.: Separation of atmosphere-ocean-vegetation feedbacks and synergies for mid-Holocene climate, Geophysical Research Letters, 36, 2009.

Pausata, F. S. R., Messori, G., and Zhang, Q.: Impacts of dust reduction on the northward expansion of the African monsoon during the Green Sahara period, Earth Planet. Sci. Lett., 434, 298-307, 2016.

1040 Perlwitz, J., Tegen, I., and Miller, R. L.: Interactive soil dust aerosol model in the GISS GCM 1. Sensitivity of the soil dust cycle to radiative properties of soil dust aerosols, J Geophys Res-Atmos, 106, 18167-18192, 2001.

Petit-Maire, N.: Natural variability of the Earth's environments: the last two climatic extremes $(18000+/-2000$ and 8000 +/- 1000 yrs BP), Comptes Rendus De L Academie Des Sciences Serie Ii Fascicule a-Sciences De La Terre Et Des Planetes, 328, 273-+, 1999.

1045 Pickett, E. J., Harrison, S. P., Hope, G., Harle, K., Dodson, J. R., Kershaw, A. P., Prentice, I. C., Backhouse, J., Colhoun, E. A., D'Costa, D., Flenley, J., Grindrod, J., Haberle, S., Hassell, C., Kenyon, C., Macphail, M., Martin, H., Martin, A. H., McKenzie, M., Newsome, J. C., Penny, D., Powell, J., Raine, J. I., Southern, W., Stevenson, J., Sutra, J. P., Thomas, I., van der Kaars, S., and Ward, J.: Pollen-based reconstructions of biome distributions for Australia, Southeast Asia and the Pacific (SEAPAC region) at 0, 6000 and 18,000 (14)C yr BP, Journal of

1050 Biogeography, 31, 1381-1444, 2004.

Potenza, M. A. C., Albani, S., Delmonte, B., Villa, S., Sanvito, T., Paroli, B., Pullia, A., Baccolo, G., Mahowald, N., and Maggi, V.: Shape and size constraints on dust optical properties from the Dome C ice core, Antarctica, Sci Rep, 6, 2016.

Prentice, I. C., Jolly, D., and participants, B.: Mid-Holocene and glacial-maximum vegetation geography of the northern continents and Africa, Journal of Biogeography, 27, 507-519, 2000.

Renssen, H., Seppa, H., Crosta, X., Goosse, H., and Roche, D. M.: Global characterization of the Holocene Thermal Maximum, Quaternary Science Reviews, 48, 7-19, 2012.

Renssen, H., Seppa, H., Heiri, O., Roche, D. M., Goosse, H., and Fichefet, T.: The spatial and temporal complexity of the Holocene thermal maximum, Nature Geoscience, 2, 410-413, 2009.

1060 Risebrobakken, B., Balbon, E., Dokken, T., Jansen, E., Kissel, C., Labeyrie, L., Richter, T., and Senneset, L.: The penultimate deglaciation: High-resolution paleoceanographic evidence from a north-south transect along the eastern Nordic Seas, Earth Planet. Sci. Lett., 241, 505-516, 2006.

Rosell-Mele, A. and Prahl, F. G.: Seasonality of U-37(K)' temperature estimates as inferred from sediment trap data, Quaternary Science Reviews, 72, 128-136, 2013.

1065 Roy, M., Dell'Oste, F., Veillette, J. J., de Vernal, A., Helie, J. F., and Parent, M.: Insights on the events surrounding the final drainage of Lake Ojibway based on James Bay stratigraphic sequences, Quaternary Science Reviews, 30, 682-692, 2011.

Royer, A., Deangelis, M., and Petit, J. R.: A 30000 year record of physical and optical-properties of microparticles from an East Antarctic ice core and implications for paleoclimate reconstruction models, Climatic Change, 5, 381$1070412,1983$.

Schilt, A., Baumgartner, M., Schwander, J., Buiron, D., Capron, E., Chappellaz, J., Loulergue, L., Schupbach, S., Spahni, R., Fischer, H., and Stocker, T. F.: Atmospheric nitrous oxide during the last 140,000 years, Earth Planet. Sci. Lett., 300, 33-43, 2010. 
Clim. Past Discuss., doi:10.5194/cp-2016-106, 2016

Manuscript under review for journal Clim. Past

Published: 25 October 2016

(c) Author(s) 2016. CC-BY 3.0 License.

Schmidt, G. A., Annan, J. D., Bartlein, P. J., Cook, B. I., Guilyardi, E., Hargreaves, J. C., Harrison, S. P., Kageyama, M., LeGrande, A. N., Konecky, B., Lovejoy, S., Mann, M. E., Masson-Delmotte, V., Risi, C., Thompson, D., Timmermann, A., Tremblay, L. B., and Yiou, P.: Using palaeo-climate comparisons to constrain future projections in CMIP5, Climate of the Past, 10, 221-250, 2014.

Schneider, R., Schmitt, J., Koehler, P., Joos, F., and Fischer, H.: A reconstruction of atmospheric carbon dioxide and its stable carbon isotopic composition from the penultimate glacial maximum to the last glacial inception, Climate of 1080 the Past, 9, 2507-2523, 2013.

Shakun, J. D., Clark, P. U., He, F., Marcott, S. A., Mix, A. C., Liu, Z. Y., Otto-Bliesner, B., Schmittner, A., and Bard, E.: Global warming preceded by increasing carbon dioxide concentrations during the last deglaciation, Nature, 484, 49-54, 2012.

Sime, L. C., Risi, C., Tindall, J. C., Sjolte, J., Wolff, E. W., Masson-Delmotte, V., and Capron, E.: Warm climate

1085 isotopic simulations: what do we learn about interglacial signals in Greenland ice cores?, Quaternary Science Reviews, 67, 59-80, 2013.

Sinclair, G., Carlson, A. E., Mix, A. C., Lecavalier, B. S., Milne, G., Mathias, A., Buizert, C., and DeConto, R.: Diachronous retreat of the Greenland ice sheet during the last deglaciation, Quaternary Science Reviews, 145, 243258, 2016.

1090 Spahni, R., Chappellaz, J., Stocker, T. F., Loulergue, L., Hausammann, G., Kawamura, K., Fluckiger, J., Schwander, J., Raynaud, D., Masson-Delmotte, V., and Jouzel, J.: Atmospheric methane and nitrous oxide of the late Pleistocene from Antarctic ice cores, Science, 310, 1317-1321, 2005.

Spahni, R., Schwander, J., Fluckiger, J., Stauffer, B., Chappellaz, J., and Raynaud, D.: The attenuation of fast atmospheric CH4 variations recorded in polar ice cores, Geophysical Research Letters, 30, 2003.

1095 Steig, E. J., Huybers, K., Singh, H. A., Steiger, N. J., Ding, Q. H., Frierson, D. M. W., Popp, T., and White, J. W. C.: Influence of West Antarctic Ice Sheet collapse on Antarctic surface climate, Geophysical Research Letters, 42, 4862-4868, 2015.

Stone, E. J., Capron, E., Lunt, D. J., Payne, T. J., Singarayer, J. S., Valdes, P. J., and Wolff, E. W.: Impact of meltwater on high-latitude early Last Interglacial climate, Clim. Past, 12, 1919-1932, 2016.

1100 Stoner, J. S., Channell, J. E. T., and Hillairemarcel, C.: Magnetic-properties of deep-sea sediments off southwest greenland - evidence for major differences between the last 2 deglaciations, Geology, 23, 241-244, 1995.

Sutter, J., Gierz, P., Grosfeld, K., Thoma, M., and Lohmann, G.: Ocean temperature thresholds for Last Interglacial West Antarctic Ice Sheet collapse, Geophysical Research Letters, 43, 2675-2682, 2016.

1105 their role in climate change during the last deglaciation, Quaternary Science Reviews, 21, 879-887, 2002.

Thompson, D. M., Ault, T. R., Evans, M. N., Cole, J. E., and Emile-Geay, J.: Comparison of observed and simulated tropical climate trends using a forward model of coral d(18)O, Geophysical Research Letters, 38, 2011.

Turney, C. S. M. and Jones, R. T.: Does the Agulhas Current amplify global temperatures during superinterglacials?, Journal of Quaternary Science, 25, 839-843, 2010.

1110 Veres, D., Bazin, L., Landais, A., Kele, H. T. M., Lemieux-Dudon, B., Parrenin, F., Martinerie, P., Blayo, E., Blunier, T., Capron, E., Chappellaz, J., Rasmussen, S. O., Severi, M., Svensson, A., Vinther, B., and Wolff, E. W.: The Antarctic ice core chronology (AICC2012): an optimized multi-parameter and multi-site dating approach for the last 120 thousand years, Climate of the Past, 9, 1733-1748, 2013.

1115 Holocene, Journal of Climate, 22, 316-330, 2009.

Viau, A. E., Gajewski, K., Sawada, M. C., and Fines, P.: Millennial-scale temperature variations in North America during the Holocene, J Geophys Res-Atmos, 111, 2006.

Vinoj, V., Rasch, P. J., Wang, H. L., Yoon, J. H., Ma, P. L., Landu, K., and Singh, B.: Short-term modulation of Indian summer monsoon rainfall by West Asian dust, Nature Geoscience, 7, 308-313, 2014.

1120 Wanner, H., Beer, J., Butikofer, J., Crowley, T. J., Cubasch, U., Fluckiger, J., Goosse, H., Grosjean, M., Joos, F., Kaplan, J. O., Kuttel, M., Muller, S. A., Prentice, I. C., Solomina, O., Stocker, T. F., Tarasov, P., Wagner, M., and Widmann, M.: Mid- to Late Holocene climate change: an overview, Quaternary Science Reviews, 27, 1791-1828, 2008 . 
Clim. Past Discuss., doi:10.5194/cp-2016-106, 2016

Manuscript under review for journal Clim. Past

Published: 25 October 2016

(c) Author(s) 2016. CC-BY 3.0 License.

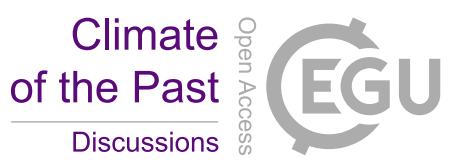

(c) (i)

1125

Winsor, K., Carlson, A. E., Klinkhammer, G. P., Stoner, J. S., and Hatfield, R. G.: Evolution of the northeast Labrador Sea during the last interglaciation, Geochem. Geophys. Geosyst., 13, 2012.

Wohlfahrt, J., Harrison, S. P., and Braconnot, P.: Synergistic feedbacks between ocean and vegetation on mid- and high-latitude climates during the mid-Holocene, Climate Dynamics, 22, 223-238, 2004.

Yoshioka, M., Mahowald, N. M., Conley, A. J., Collins, W. D., Fillmore, D. W., Zender, C. S., and Coleman, D. B.: Impact of desert dust radiative forcing on Sahel precipitation: Relative importance of dust compared to sea surface temperature variations, vegetation changes, and greenhouse gas warming, Journal of Climate, 20, 1445-1467, 2007. 
Clim. Past Discuss., doi:10.5194/cp-2016-106, 2016

Climate

Manuscript under review for journal Clim. Past

Published: 25 October 2016

(c) Author(s) 2016. CC-BY 3.0 License.

Discussions

Table 1. Forcings and boundary conditions. More details can be found in the Section numbers indicated in parentheses.

\begin{tabular}{|c|c|c|c|}
\hline & $\begin{array}{l}1850 \text { C.E. (DECK } \\
\text { piControl })^{1}\end{array}$ & $6 \mathrm{ka}(\text { midHolocene })^{2}$ & $127 \mathrm{ka}(\operatorname{lig} 127 k)^{2}$ \\
\hline Orbital parameters $(2.1)$ & CMIP DECK piControl & & \\
\hline Eccentricity & 0.0167643 & 0.018682 & 0.039378 \\
\hline Obliquity (degrees) & 23.459277 & 24.105 & 24.040 \\
\hline Perihelion - 180 & 100.32687 & 0.87 & 275.41 \\
\hline Vernal equinox & Fixed to noon on March 21 & Fixed to noon on March 21 & Fixed to noon on March 21 \\
\hline \multicolumn{4}{|l|}{ Greenhouse gases (2.2) } \\
\hline Carbon dioxide (ppm) & 284.6 & 264.4 & 275 \\
\hline Methane (ppb) & 808 & 597 & 685 \\
\hline Nitrous oxide (ppb) & 273 & 262 & 255 \\
\hline Other GHG gases & CMIP DECK piControl & 0 & 0 \\
\hline Solar constant $\left(\mathrm{Wm}^{-2}\right)(2.1)$ & TSI: 1360.747 & Same as piControl & Same as piControl \\
\hline CMIP DECK piControl & SSI, ap if needed & & \\
\hline Paleogeography (2.3) & Modern & Same as piControl & Same as piControl \\
\hline Ice sheets (2.3) & Modern & Same as piControl & Same as piControl \\
\hline Vegetation (2.5) & CMIP DECK piControl & $\begin{array}{l}\text { Prescribed or interactive as } \\
\text { in piControl }\end{array}$ & $\begin{array}{l}\text { Prescribed or interactive as } \\
\text { in piControl }\end{array}$ \\
\hline $\begin{array}{l}\text { Aerosols (2.6) } \\
\text { Dust, Volcanic, etc. }\end{array}$ & CMIP DECK piControl & $\begin{array}{l}\text { Prescribed or interactive as } \\
\text { in piControl }\end{array}$ & $\begin{array}{c}\text { Prescribed or interactive as } \\
\text { in piControl }\end{array}$ \\
\hline
\end{tabular}

\footnotetext{
${ }^{1}$ More information on the CMIP DECK piControl and CMIP6 historical protocols can be found at:

http://www.wcrp-climate.org/wgcm-cmip/wgcm-cmip6

${ }^{2}$ Datasets for midHolocene and lig127k are available on the PMIP4 web page:
} 
Clim. Past Discuss., doi:10.5194/cp-2016-106, 2016

Climate

Manuscript under review for journal Clim. Past

Published: 25 October 2016

(c) Author(s) 2016. CC-BY 3.0 License.

Table 2. Summary of PMIP4 Tier 2 sensitivity simulations complementing PMIP4/CMIP6

Tier 1 interglacial experiments. More details can be found in the Section numbers indicated in parentheses.

\begin{tabular}{|c|c|c|}
\hline \multicolumn{3}{|l|}{ PMIP4-CMIP6 (Tier 1 simulations) } \\
\hline & Entry card: midHolocene & $\operatorname{lig} 127 k$ \\
\hline \multicolumn{3}{|c|}{ PMIP4 sensitivity experiments: Tier 2 simulations } \\
\hline Experiments & Holocene & Last Interglacial \\
\hline $\begin{array}{l}\text { Orbital forcing and trace gases } \\
\text { (3.1) }\end{array}$ & $\begin{array}{l}\text { hol9.5k: Early Holocene } \\
\text { - Orbital: } 9.5 \mathrm{ka} \\
\text { - Ice sheet: ICE-6G or GLAC-1D } \\
\text { reconstruction }{ }^{1} \\
\text { - GHG: same as for the } \\
\text { deglaciation experiment }^{1}\end{array}$ & $\begin{array}{l}\text { lig116k: Glacial inception } \\
\text { - Orbital: } 116 \mathrm{ka} \\
\text { - } \mathrm{CO}_{2}: 280,240 \mathrm{ppm} \\
\text { - Other forcings and boundary } \\
\text { conditions: as for lig } 127 \mathrm{k}\end{array}$ \\
\hline Sensitivity to vegetation (3.2) & $\begin{array}{l}\text { midHolocene_veg } \\
\text { - prescribed boreal forests in } \\
\text { Arctic and shrub/savanna over } \\
\text { Sahara } \\
\text { - vegetation reconstructions }{ }^{2} \\
\text { - midHolocene equilibrium veg } \\
\text { with dgvm in piControl } \\
\end{array}$ & $\begin{array}{l}\text { lig127k_veg } \\
\text { - prescribed boreal forests in } \\
\text { Arctic and shrub/savanna over } \\
\text { Sahara }\end{array}$ \\
\hline Sensitivity to Ice-Sheet (3.3) & & $\begin{array}{l}\text { lig127k_ais and lig127k_gris } \\
\text { - Antarctic ice sheet at its } \\
\text { minimum LIG extent } \\
\text { - Greenland ice sheet at its } \\
\text { minimum LIG extent }\end{array}$ \\
\hline Test to freshwater flux (3.4) & $\begin{array}{l}\text { hol8.2k: } 8.2 \text { ka event } \\
\text { - Orbital: } 8.2 \mathrm{ka} \\
\text { - Ice sheet: ICE-6G or GLAC-1D } \\
\text { reconstruction }{ }^{1} \\
\text { - GHG: same as for the } \\
\text { deglaciation experiment } \\
\text { - Initial state: } 8.5 \text { ka simulation } \\
\text { - Meltwater flux of } 2.5 \mathrm{~Sv} \text { for one } \\
\text { year added to the Labrador Sea } \\
\text { plus } 0.05 \mathrm{~Sv} \text { for } 500 \text { years } \\
\text { - Run length: preferably until } \\
\text { evidence for the recovery of the } \\
\text { AMOC. }\end{array}$ & $\begin{array}{l}\text { lig127k_H11: Heinrich } 11 \\
\text { meltwater event } \\
\text { - Meltwater flux of } 0.2 \mathrm{~Sv} \text { to the } \\
\text { North Atlantic between } 50 \text { and } \\
70^{\circ} \mathrm{N} \text { for } 1000 \text { years } \\
\text { - Other forcings and boundary } \\
\text { conditions: as for } l i g 127 k \\
\text { - Initial state: lig } 127 k \text { simulation }\end{array}$ \\
\hline $\begin{array}{l}\text { Transient simulations (3.5) } \\
\text { (Note : Exploratory and flexible set } \\
\text { up) }\end{array}$ & $\begin{array}{l}\text { past6k: transient Holocene } \\
\text { - Transient evolution in Earth's } \\
\text { orbit and trace gases } \\
\text { - Other boundary conditions (land } \\
\text { use, solar, volcanism) may be } \\
\text { considered by some groups } \\
\text { - Initial state: midHolocene }\end{array}$ & $\begin{array}{l}\text { lig128to122k: transient LIG } \\
\text { - Transient evolution in Earth's } \\
\text { orbit and trace gases } \\
\text { - Other boundary conditions (ice } \\
\text { sheets) may be considered by } \\
\text { some groups } \\
\text { - Initial state: last } 127 k\end{array}$ \\
\hline
\end{tabular}

${ }^{\mathrm{I}}$ Ivanovic et al., 2016; available on the PMIP4 web page

${ }^{2}$ Hoelzmann et al., 1998; Bigelow et al., 2003; available on the PMIP4 web page 
Clim. Past Discuss., doi:10.5194/cp-2016-106, 2016

Manuscript under review for journal Clim. Past

Published: 25 October 2016

(c) Author(s) 2016. CC-BY 3.0 License.

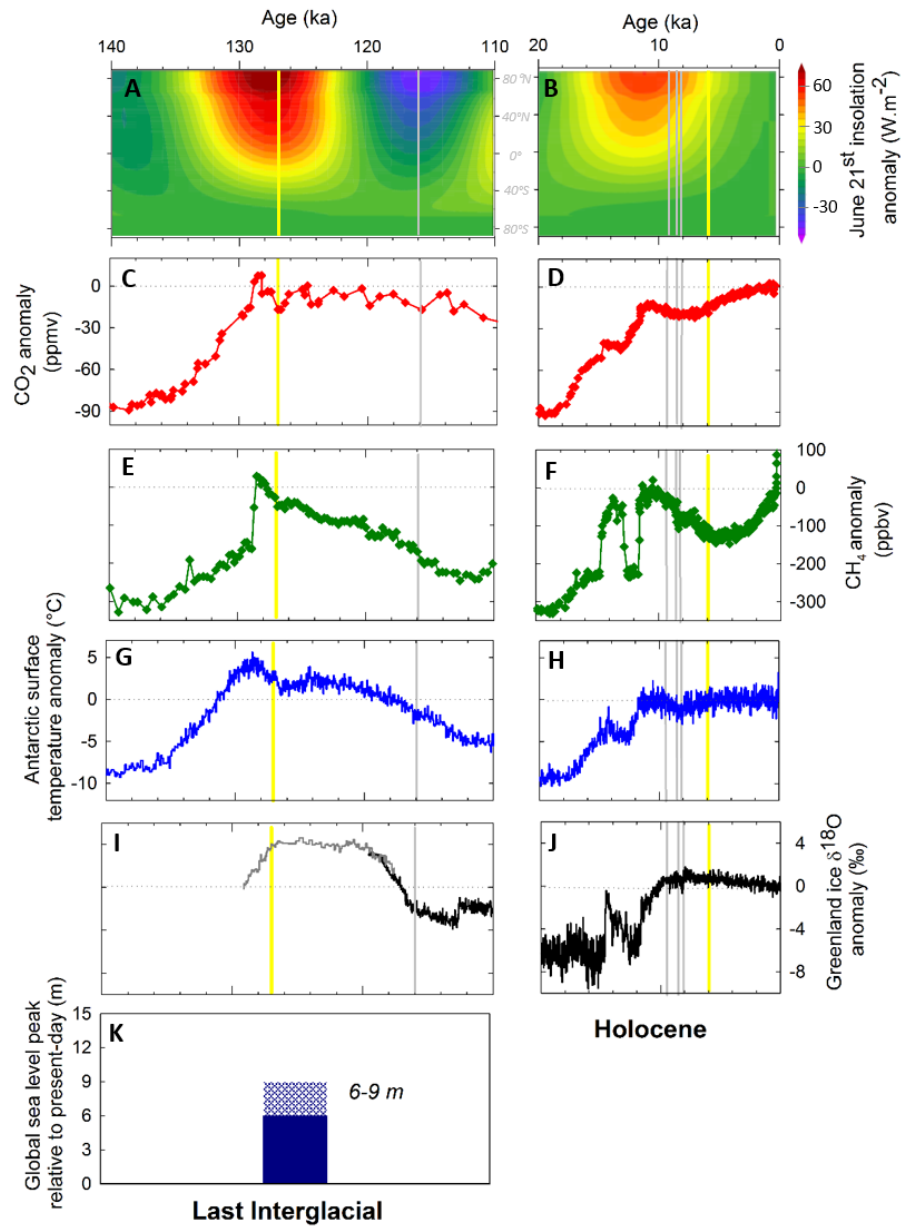

1145 Figure 1: Forcing and climatic records across the Last Interglacial (LIG, left) and the Holocene (right). Records are displayed in panels $\mathbf{A}$ ) to $\mathbf{J}$ ) as anomalies relative to their average value of the last 1000 years. $\mathbf{A}$ and $\mathbf{B}$ ) $21^{\text {st }}$ June insolation across latitudes; $\mathbf{C}$ and D) Atmospheric $\mathrm{CO}_{2}$ concentration (Siegenthaler et al. 2005; Schneider et al. $2013 \mathrm{CP}$, Monnin et al. 2004); $\mathbf{E}$ and F) Atmospheric $\mathrm{CH}_{4}$ concentration (Loulergue et al. 2008); $\mathbf{G}$ and $\mathbf{H}$ ) Antarctic surface air temperature reconstruction (Jouzel et al. 2007); $\mathbf{I}$ and $\mathbf{J}$ ) Greenland ice $\delta^{18} \mathrm{O}$ : from NEEM ice 1150 core (NEEM community members 2012) in dark grey and from NGRIP ice core (NGRIP project members 2004) in black. Note that NEEM ice $\delta^{18} \mathrm{O}$ is shifted by $+2 \%$. K) LIG maximum global mean sea level (GMSL) relative to present-day, uncertainties in the amplitude are indicated by the shading (see Dutton et al. 2015 for a review). No significant sea level variations are reported throughout the Holocene compared to present-day. NGRIP ice $\delta^{18} \mathrm{O}$ is displayed on the GICC05 annual layer-counted timescale (Svensson et al. 2008) over the last $20 \mathrm{ka}$ and on the AICC2012 chronology across the 119-110 ka time interval. All other ice core records are displayed on the AICC2012 chronology which is coherent by construction with the GICC05 time scale over the last 60 ka (Bazin et al. 2012, Veres et al. 2012). Vertical yellow lines indicate 127 and $6 \mathrm{ka}$, the time intervals chosen to run the coordinated PMIP4-CMIP6 lig127k and midHolocene simulations. Vertical grey lines represent the 116, 9.5, 8.5 and 8.2 ka time intervals for which additional sensitivity simulations will be run within PMIP4. 
Clim. Past Discuss., doi:10.5194/cp-2016-106, 2016

Manuscript under review for journal Clim. Past

Published: 25 October 2016

(c) Author(s) 2016. CC-BY 3.0 License.

Climate of the Past

Discussions

(c) (1)

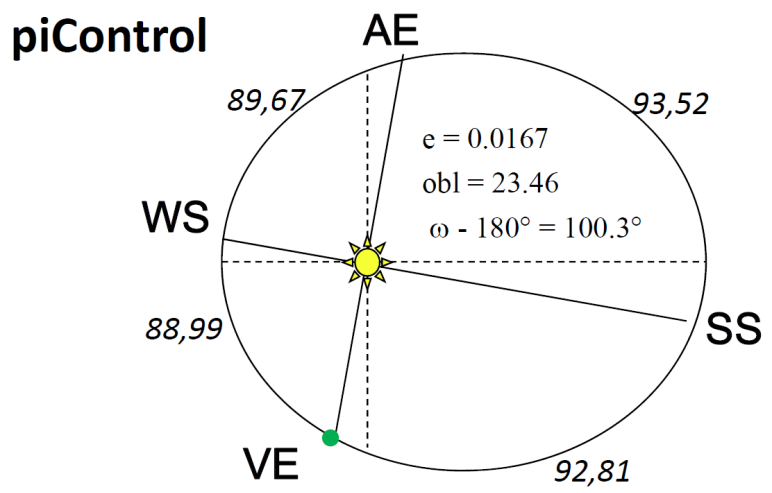

\section{midHolocene SS}
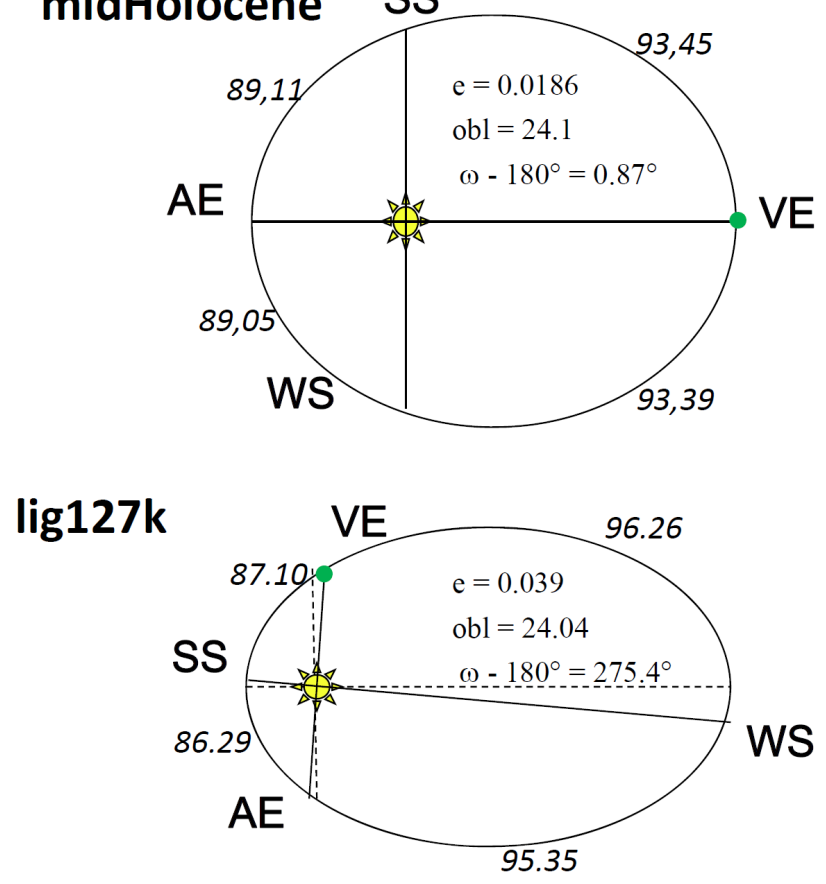

1160

Figure 2. Orbital configuration for piControl, midHolocene, and lig $127 \mathrm{k}$ experiments. Note that aspect ratio between the two axes of the ellipse has been magnified to better highlight the differences between the periods. However, the change in ratio between the different periods is proportional to the real values. In these graphs VE stands for vernal equinox, SS for summer solstice, AE for autumnal equinox, and WS for winter solstice. The numbers along the ellipse are the number of days between solstices and equinoxes. 
Clim. Past Discuss., doi:10.5194/cp-2016-106, 2016

Manuscript under review for journal Clim. Past

Published: 25 October 2016

(c) Author(s) 2016. CC-BY 3.0 License.
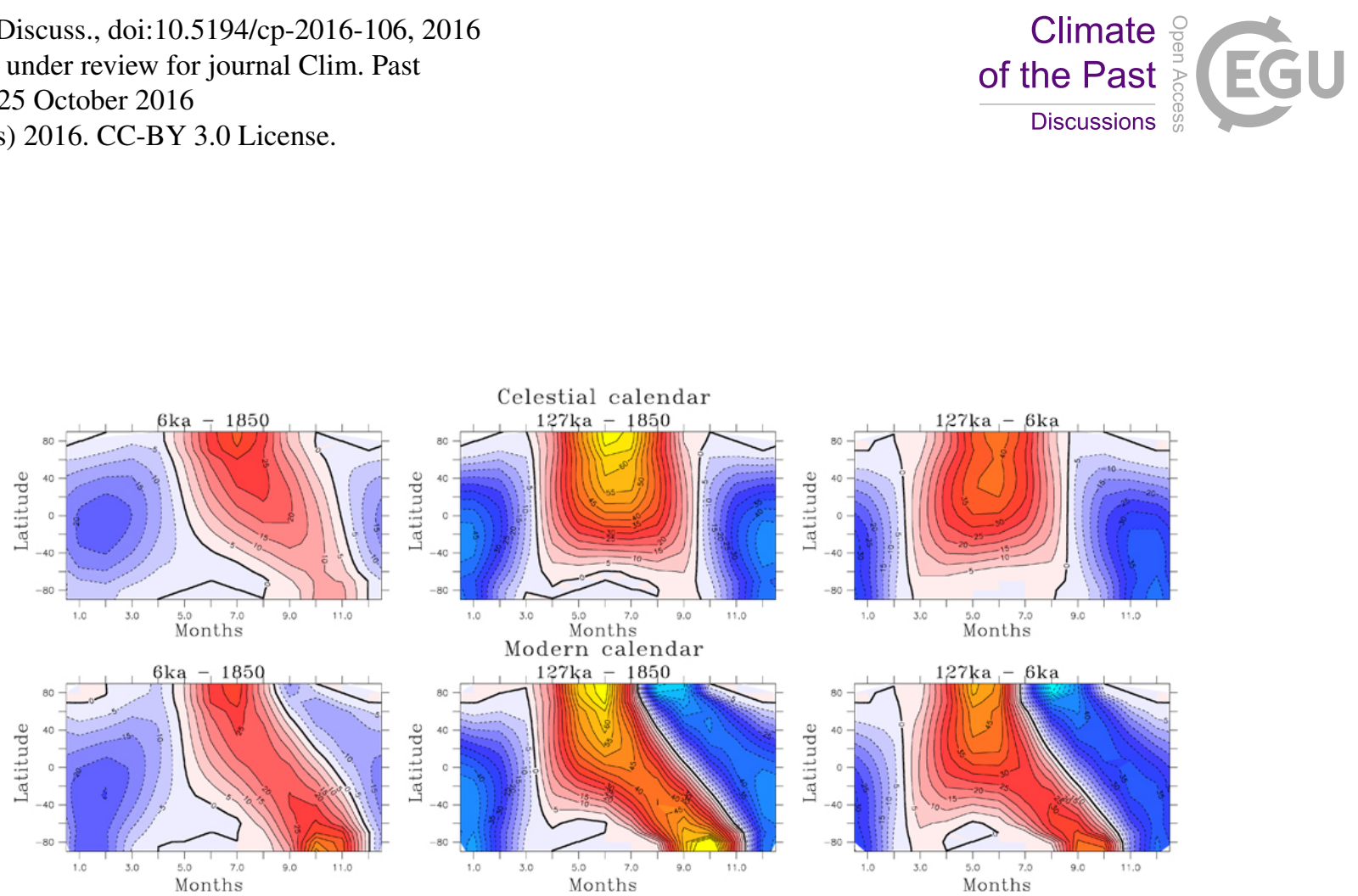

Figure 3. Latitude-month insolation anomalies (127ka-1850, 6ka-1850, 127ka-6ka) computed using either the celestial calendar (top) or the modern calendar (bottom), with vernal equinox on March 21 at noon, to compute monthly averages $\left(\mathrm{W} \mathrm{m}^{-2}\right)$.
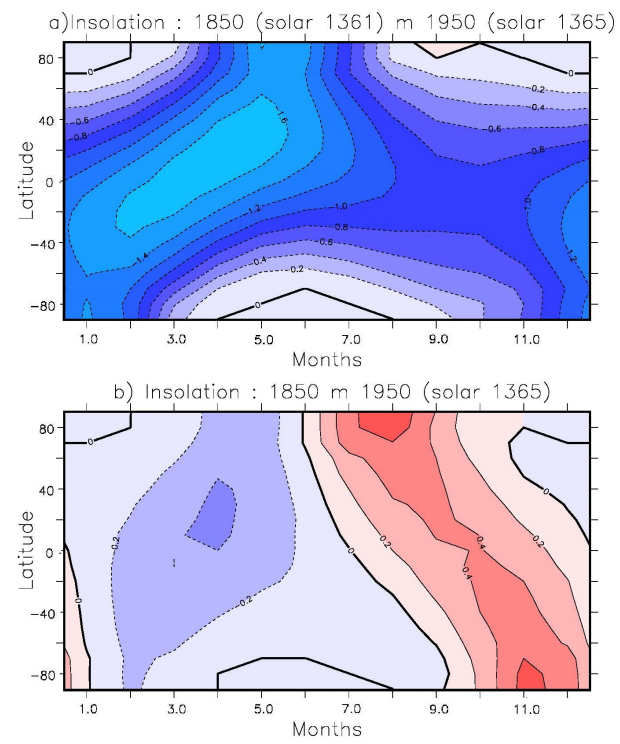

1175 Figure 4. Difference in incoming solar radiation at the top of the atmosphere $\left(\mathrm{W} \mathrm{m}^{-2}\right)$ between PMIP4 and PMIP3 protocols, a) considering the changes in Earth's orbital parameters between 1850 and 1950 and the reduction of the solar constant from 1365 to 1360.7 between these two PMIP phases and b) only the changes in Earth's orbital parameters. 
Clim. Past Discuss., doi:10.5194/cp-2016-106, 2016

Manuscript under review for journal Clim. Past

Published: 25 October 2016

(c) Author(s) 2016. CC-BY 3.0 License.

(c) (i)

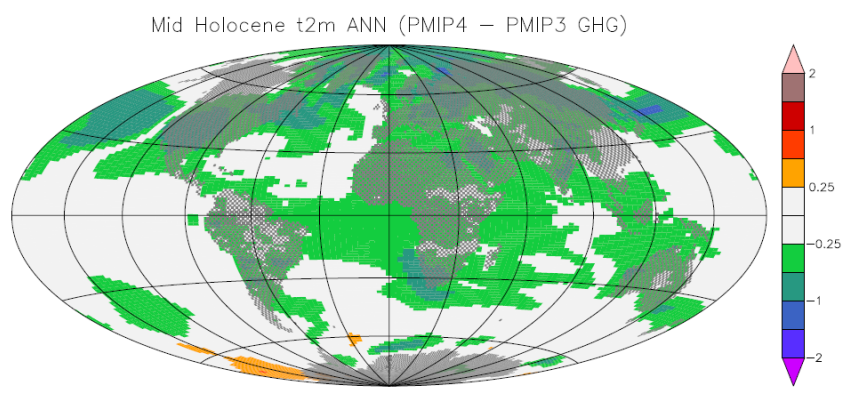

Mid Holocene pr ANN (PMIP4 - PMIP3 GHG)

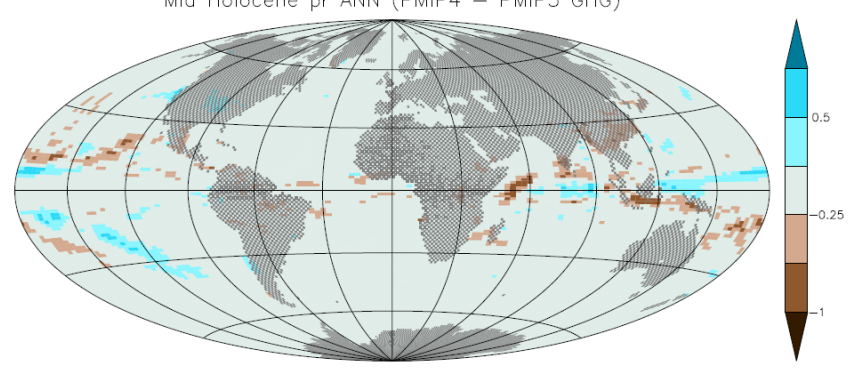

Figure 5. Impact of the changes in trace gases between PMIP3 and PMIP4 on temperature $\left({ }^{\circ} \mathrm{C}\right)$ and precipitation $\left(\mathrm{mm} \mathrm{d}^{-1}\right)$ as estimated with the IPSLCM5A model. Only significant values are plotted in colors. 
Clim. Past Discuss., doi:10.5194/cp-2016-106, 2016

Manuscript under review for journal Clim. Past

Published: 25 October 2016

(c) Author(s) 2016. CC-BY 3.0 License.

a. Dust sources (Albani)

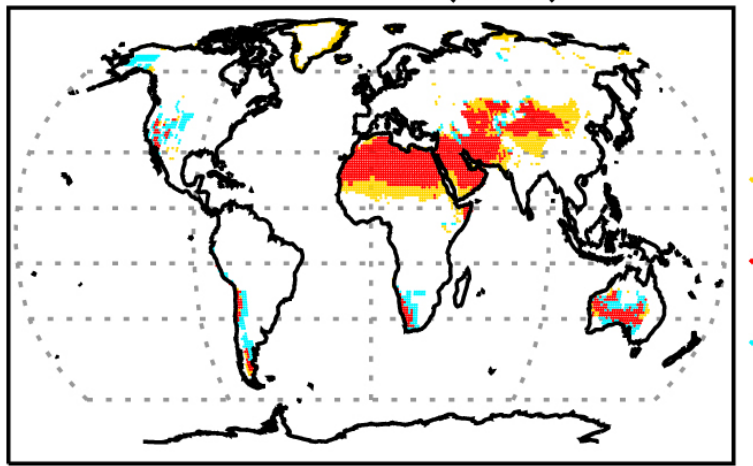

a. MH Dust deposition flux (Albani)
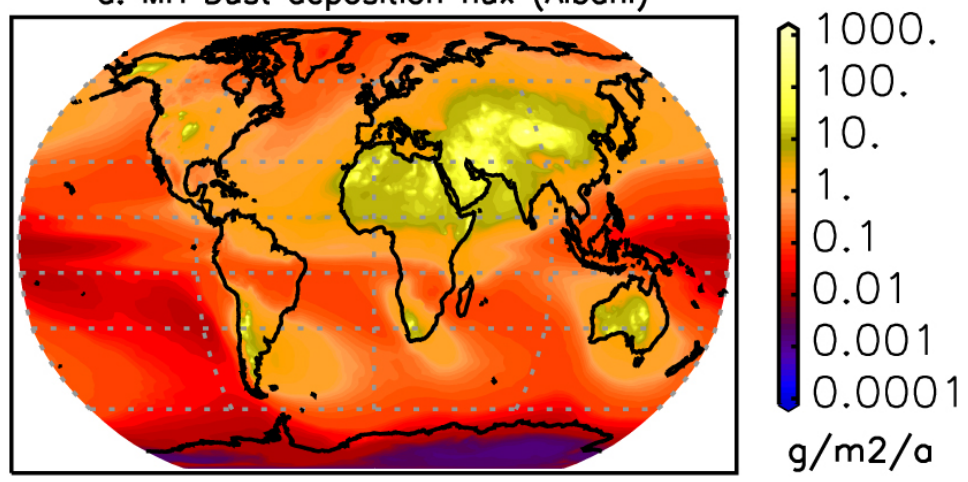

c. $\mathrm{MH} / \mathrm{PI}$ ratio in dust deposition
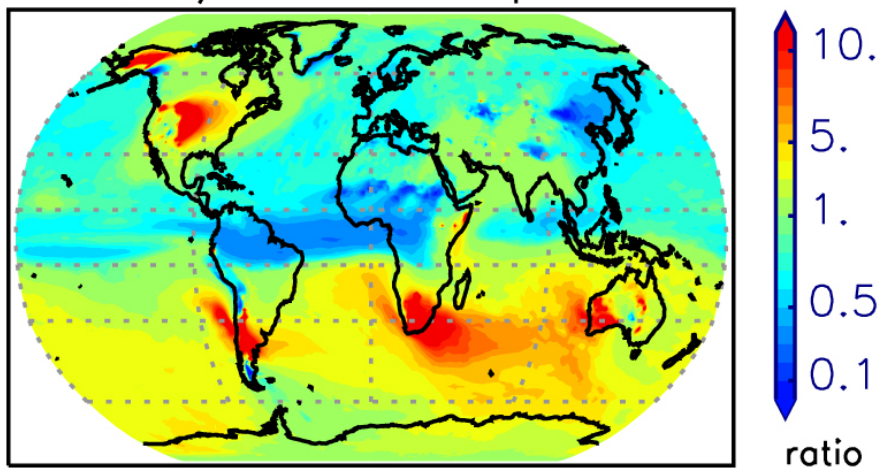

Figure 6. Maps of dust from observationally-constrained simulations with the Community Climate System Model for the midHolocene (Albani et al., 2015). a. Active sources for dust emissions for the midHolocene and the piControl (Albani et al., 2016). b. Dust deposition $\left(\mathrm{g} \mathrm{m}^{-2} \mathrm{a}^{-1}\right)$ in the midHolocene. c. Ratio of midHolocene / piControl dust deposition. 